$\mathcal{E}_{\text {Iransport Forum }}^{\text {International }}$

\title{
Are We Heading Towards a Reversal of the Trend for Ever-Greater Mobility?
}

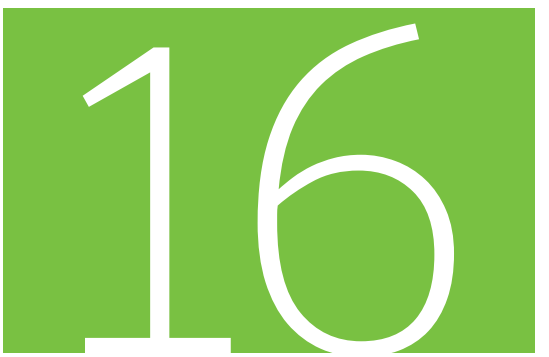

Discussion Paper 2012 • 16

J.-L. Madre, R. Collet,

I. T. Villareal

UPE, IFSTTAR, DEST, Noisy-le-Grand, France

Y. D. Bussière

Facultad de Economía, BUAP, Puebla, Mexico 
Are We Heading Towards a Reversal of the Trend for Ever-Greater Mobility?

Discussion Paper No. 2012-16

Prepared for the Roundtable on

Long-Run Trends in Travel Demand

29-30 November 2012

\section{Jean-Loup MADRE, ${ }^{1}$ \\ Yves D. BUSSIÈRE, ${ }^{2}$ \\ Roger COLLET ${ }^{1}$ \\ Irving Tapia VILLAREAL ${ }^{1}$}

${ }^{1}$ UPE, IFSTTAR, DEST

2 rue de la Butte Verte,

93166 Noisy-le-Grand Cedex, France.

${ }^{2}$ Facultad de Economía, BUAP, Av. San Claudio y 22 Sur s/n, San Manuel, Ciudad Universitaria,

72240 Puebla, Mexico

October 2012 


\section{INTERNATIONAL TRANSPORT FORUM}

The International Transport Forum at the OECD is an intergovernmental organisation with 54 member countries. It acts as a strategic think tank with the objective of helping shape the transport policy agenda on a global level and ensuring that it contributes to economic growth, environmental protection, social inclusion and the preservation of human life and well-being. The International Transport Forum organizes an annual summit of Ministers along with leading representatives from industry, civil society and academia.

The International Transport Forum was created under a Declaration issued by the Council of Ministers of the ECMT (European Conference of Ministers of Transport) at its Ministerial Session in May 2006 under the legal authority of the Protocol of the ECMT, signed in Brussels on 17 October 1953 , and legal instruments of the OECD.

The members of the Forum are: Albania, Armenia, Australia, Austria, Azerbaijan, Belarus, Belgium, Bosnia-Herzegovina, Bulgaria, Canada, Chile, China, Croatia, the Czech Republic, Denmark, Estonia, Finland, France, FYROM, Georgia, Germany, Greece, Hungary, Iceland, India, Ireland, Italy, Japan, Korea, Latvia, Liechtenstein, Lithuania, Luxembourg, Malta, Mexico, Moldova, Montenegro, Netherlands, New Zealand, Norway, Poland, Portugal, Romania, Russia, Serbia, Slovakia, Slovenia, Spain, Sweden, Switzerland, Turkey, Ukraine, the United Kingdom and the United States.

The International Transport Forum's Research Centre gathers statistics and conducts co-operative research programmes addressing all modes of transport. Its findings are widely disseminated and support policymaking in member countries as well as contributing to the annual Summit.

\section{DISCUSSION PAPERS}

The International Transport Forum's Discussion Paper Series makes economic research, commissioned or carried out at its Research Centre, available to researchers and practitioners. The aim is to contribute to the understanding of the transport sector and to provide inputs to transport policy design. The Discussion Papers are not edited by the International Transport Forum and they reflect the author's opinions alone.

The Discussion Papers can be downloaded from:

$\underline{\text { www.internationaltransportforum.org/jtrc/DiscussionPapers/jtrcpapers.html }}$

The International Transport Forum's website is at:

www.internationaltransportforum.org or for further information on the Discussion Papers, please email: itf.contact@oecd.org 


\section{TABLE OF CONTENTS}

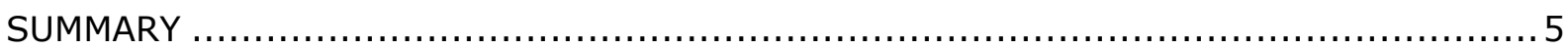

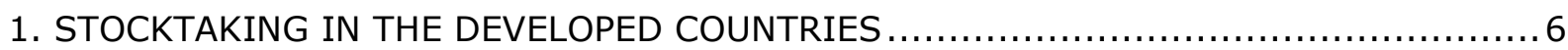

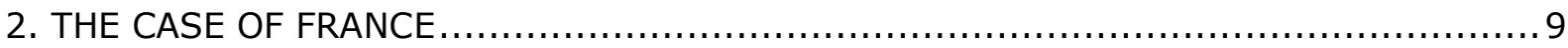

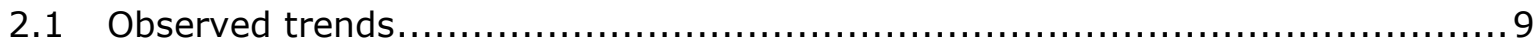

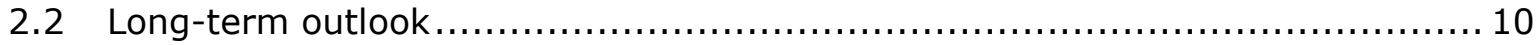

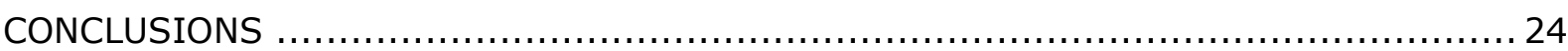

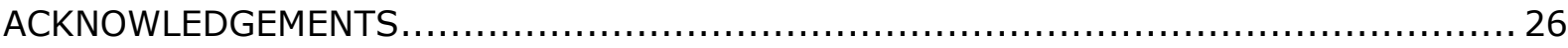

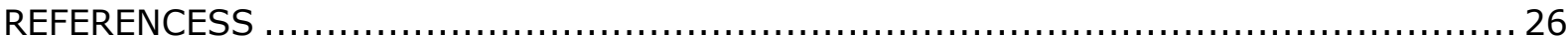

London, October 2012 


\section{SUMMARY}

In most industrialised countries, it can be seen that urban mobility and car traffic have stagnated since the early 2000s. In France, the report on traffic conducted by the National Transport Accounts Commission shows a similar break in the trend, which was confirmed by household travel surveys (EMDs) in most major cities, including Lille, Lyon and Strasbourg, and later by the National Transport and Travel Survey (ENTD), which shows that the trend can be attributed primarily to people living in large urban areas and provides an overall view of mobility: trips have become less frequent (with unbroken workdays) and less exclusively taken by car (as more young adults adopt multimodal behaviours), and car ownership is decreasing in the centre of greater Paris, as, for that matter, in the centre of London.

Does this levelling-off of traffic suggest that the saturation point is near (with a decoupling of traffic and income trends in the most densely populated areas or above a certain standard of living) or, rather, a cancelling out of opposite trends (continued growth in rural and suburban areas and decline amongst residents of the most densely populated areas)? Is this a structural phenomenon (population ageing, etc.) or a cyclical one linked to rising and volatile fuel prices and the recession?

We shall explore these issues in the light of data collected in France, supplemented by selected data from other developed countries, and then move on to a comparison with a number of Mexican cities in order to consider the extent to which, and in what timeframe, these trends could spread southward to the emerging economies.

Keywords: Outlook, mobility, car ownership, reversal of trend. 


\section{STOCKTAKING IN THE DEVELOPED COUNTRIES}

Internationally, after expanding rapidly in the 1960 s and 70 s, growth in road traffic (as a per capita average) slowed and seemed to approach the saturation point in a number of industrialised countries [Litman, 2009; Millard-Ball and Schipper, 2010; Newman \& Kenworthy, 2011] (see Figure 1). The Australian Bureau of Infrastructure, Transport and Regional Economics, which has compiled a long series for 25 countries, explains this trend as a reflection of fuel prices and economic activity, as well as a time-related saturation effect [BITRE, 2012]. A comprehensive analysis of global transport demand trends over the next 40 years was presented by the JTRC/ITF in May 2011 in Leipzig [OECD/ITF, 2011]. Having noted an apparent saturation in the developed countries, this working group nonetheless took a critical view of extrapolating demand on the basis of this assumption alone, stressing the need to take account of such other factors as rising fuel prices and the distribution of wealth, as well as the scope of future transport demand trends in the emerging economies. Our preliminary research on two Mexican cities shows that this levelling-off of mobility could occur there around 2030.

In most developed countries, the proportion of people holding driving licences at any given age had always been on the rise as compared with previous generations, and the increase had been greater for women than for men, thus indicating that their respective behaviour patterns were becoming more similar. It has now been found that the licenceholding percentage among young people has started to decline in some 10 countries [Sivak and Schoettle, 2012], in parallel with the development of the Internet, and that this is especially perceptible in the case of young males; these countries are located in North America (Canada and the USA), where the spread of the automobile began in the 1930s, in the Nordic regions (Norway and Sweden, but not Finland), in western Europe (United Kingdom, France and Germany, but neither Switzerland nor the Netherlands), and in the most densely populated areas of the Far East (Japan and South Korea); the flourishing of car ownership is too recent in central Europe (Poland, Latvia), and to a lesser extent the Mediterranean countries (Spain, Israel), for such a phenomenon to be observable yet. In France, the decline in the number of licence-holders could be attributed to the abolition in 1997 of compulsory military service, which had enabled young men to start driving at virtually no cost to themselves [Avrillier et al., 2010].

According to a comparative study of young adults (aged 20 to 29) in six industrialised countries (Germany, United Kingdom, France, Japan, Norway and the United States), between 1975 and 2010, in most countries, the average distance travelled peaked around the end of the 1990s, or at the beginning of the 2000s in the United States, and subsequently declined (Figure 2). Thus, young people are less likely to have a driving licence and to travel exclusively by car than youth in the previous generation [Kuhnimohf et al., 2012]. There are a number of possible explanations for this phenomenon: the fact that a growing proportion of young people pursue higher education, which defers their entry into the labour market; the tendency to start a family at a later age; rising fuel prices; the introduction of demand-management measures to reduce car traffic in cities; and lastly, a change in mentalities. 
Figure 1 International Vehicle Travel Trends (Litman 2006)

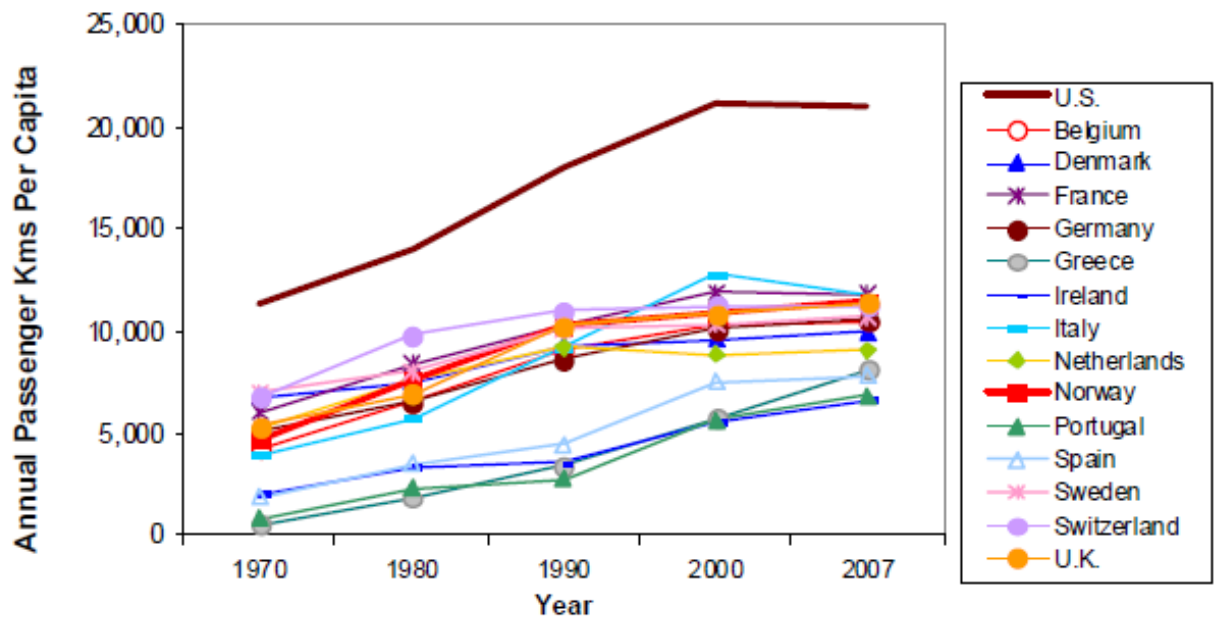

Per capita vehicle travel grew rapidly between 1970 and 1990, but has since leveled off in most $O E C D$ countries, and is much lower in European countries than in the U.S.

Source: Litman, Todd (2009). Evaluation Public Transit Benefits and Costs. Best Practices Guidebook. Victoria Transport Policy Institute. www.vtpi.org.

Figure 2. Vehicle-km trends (car driver and car passengers) per traveller, per day for young adults aged 20-29 (6 countries)

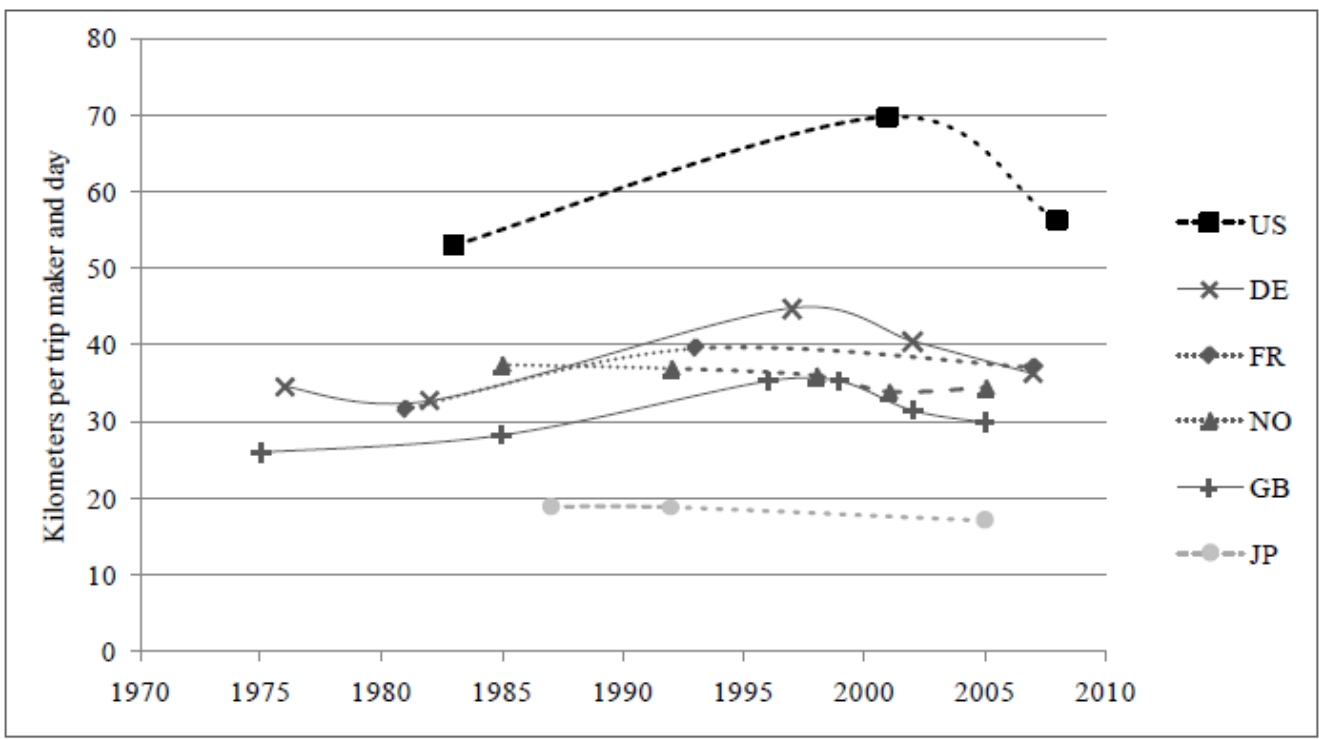

Source: Kuhnimohf et al. (2012).

For the United Kingdom, [Metz , 2010] observes that over the past 30 years the average travel time has remained stable at about 1 hour per day ( 375 hours per person per year), as has the average number of trips ( 1000 trips per person per year). Car ownership has more than doubled, as have speeds, which in combination with rising income prompted a substantial increase in distances travelled, until a certain levelling-off as from the mid-1990s (Figure 3). 
Metz puts forward a number of explanations for the levelling-off of traffic: fewer local trips due to longer absences from home [Madre and Armoogum, 1997], worsening congestion, fewer trips as a result of strides in telecommunications, and structural saturation of the demand for travel.

Figure 3. Travel time (hours per person per year), distance (miles per person per year) in the UK

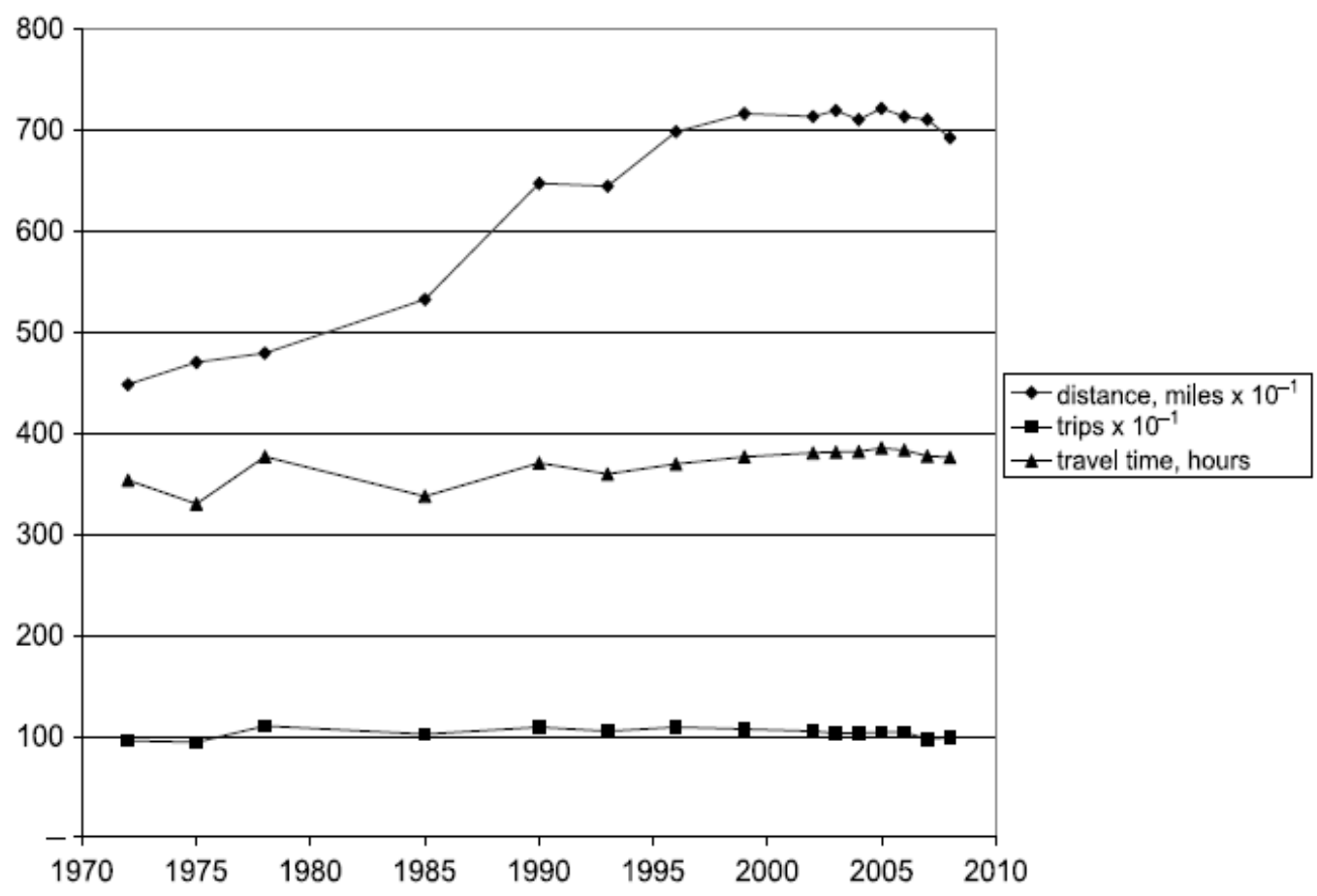

Source: NTS 2008, Table 2.1 in [Metz, 2010], p. 661.

Do the trends being observed reflect the approach of the saturation point via a decoupling of the growth rates for traffic and income? [Millard-Ball and Schipper, 2010]. Is this decoupling manifesting itself first in the most densely populated regions and/or over a certain standard of living? Or does the levelling-off of traffic result rather from a cancelling out of opposite trends (continued growth in rural and suburban areas and decline amongst residents of the most densely populated areas) [Goodwin, 2010-2011]? Some authors even posit the assumption of a reduction in travel in the developed countries in the short and medium terms, attributable to a variety of socio-economic factors [Litman, 2011]. One could well ask whether this is a socio-demographic phenomenon (population ageing, re-densification of large centre-city areas, fewer but more-intensive workdays, with no returning home for lunch, etc.) or an economic one linked to rising and volatile fuel prices and the recession [Gardes et al., 1996; Collet, 2012].

The Mobility Research Task Force (ERA-MOB) of IFSTTAR's DEST laboratory has undertaken an analysis of the behavioural changes [Quételard, 2011] that are observed, for example, when people move house [Meissonier, 2011]. Among other things, these changes are obviously a key consideration with regard to the outlook for energy and the environment. 


\section{THE CASE OF FRANCE}

\subsection{Observed trends}

In France, since the mid-2000s the report on traffic conducted by the National Transport Accounts Commission has also shown a levelling-off of road traffic [CCTN, 2012]: passenger car traffic has experienced no truly significant growth since 2003, i.e. not since petrol prices have been headed clearly upwards [SOeS, 2012]. The sole example of steeper growth after 2003 than before it is for buses and coaches, showing the vitality of collective transport. This reversal of the prior trend towards ever-greater mobility has been confirmed by household travel surveys (EMDs) in Lyon, Lille, Rouen, Reims, Rennes and Strasbourg, amongst others [Papon, Hivert, 2008; Quételard, 2011], and subsequently by the National Transport and Travel Survey (ENTD), which attributes this essentially to the inhabitants of major metropolitan areas [Hubert, 2009] and puts it back into an overall vision of mobility: travel by working people and students has become less frequent as uninterrupted work/school days have become the norm [Hubert et al., 2010], and the travel is less exclusively via cars. Consequently, rising fuel prices are probably not the only factor reversing the growth of individual mobility; alterations to the scheduling of activities (shorter working hours, teleworking, teleshopping, etc.) lessen the transport burden, making the reputedly most practical mode - the automobile - less indispensable for city-dwellers. Along with the decline of individual car traffic there has been a concomitant decline in the prevalence of household car ownership: this has been decreasing, even in the hearts of such major cities as London and Paris [STIF, 2012].

According to the national transport surveys, it is only in the 18 to 24 age bracket that a decline in the percentage of driving licence-holders has been observed - a decline that is especially pronounced in areas under urban influence (such as Île-de-France) (Table 1); the decline vanishes in the 25 to 35 bracket, but too much time elapsed between the 1993-94 and 2007-08 surveys to justify the assertion that there has been a catching-up, insofar as the cohort aged 18 to 24 in 1994 were between 32 and 38 in 2008 [Roux, 2012]. Thanks to surveys less staggered over time, it can be noted that there was no catch-up in Lille, since the percentage of driving licence-holders aged 25 to 34 was also down in 2006, as compared with 1998. Elsewhere, as in the United Kingdom, the disinterest in driving licences has been attributed to the introduction of a theoretical test in mid-1996, even if a downturn has been observable since 1993 [Noble, 2005]. In the United States as well, the decline in driving licences can be seen to coincide with a toughening of the tests administered in the various states [Davis et al., 2012]. 
Table 1. Proportion of young adults holding driving licences by area of residence: île-de-France (IdF), non-IdF, 1980s-2000s (as a \%)

\begin{tabular}{|c|c|c|c|c|c|}
\hline \multicolumn{7}{|c|}{ Aged 18-24 } \\
\hline Date & $\begin{array}{c}\text { Mostly rural } \\
\text { community } \\
\text { non-IdF }\end{array}$ & $\begin{array}{c}\text { Mostly urban } \\
\text { community } \\
\text { non-IdF }\end{array}$ & e.g. Lille & IdF & $\begin{array}{c}\text { France as a } \\
\text { whole }\end{array}$ \\
\hline $1980 \mathrm{~s}$ & 75.7 & 59.9 & 58.7 & 59.7 & 62.3 \\
\hline $1990 \mathrm{~s}$ & 69.5 & 69.6 & 64.5 & 56.8 & 66.9 \\
\hline $2000 \mathrm{~s}$ & 78.6 & 67.8 & 54.0 & 48.7 & 65.7 \\
\hline \multicolumn{7}{|c|}{ Aged 25-34 } \\
\hline Date & $\begin{array}{c}\text { Mostly rural } \\
\text { community } \\
\text { non-IdF }\end{array}$ & $\begin{array}{c}\text { Mostly urban } \\
\text { community } \\
\text { non-IdF }\end{array}$ & e.g. Lille & IdF & $\begin{array}{c}\text { France as a } \\
\text { whole }\end{array}$ \\
\hline $1980 \mathrm{~s}$ & 87.8 & 81.2 & 81.9 & 78.2 & 81.9 \\
\hline $1990 \mathrm{~s}$ & 91.7 & 87.6 & 85.7 & 78.9 & 86.7 \\
\hline $2000 \mathrm{~s}$ & 95.8 & 88.3 & 80.1 & 81.6 & 88.5 \\
\hline
\end{tabular}

Sources: National Transport Surveyls (ENTs) for 1981, 1993 and 2007; Household Travel Surveys (EMDs) for Lille for 1987, 1998 and 2006

\subsection{Long-term outlook}

The slowdown in individual car use and ownership raises the question of their future trajectories. Three scenarios are theoretically feasible [Goodwin, 2010-2011; Collet et al., 2012]:

1) Resumed growth after the current pause;

2) Saturation at levels to be specified; or

3) A reversal of the trend after peaking to a plateau, to be specified as well.

What frameworks need to be formulated in order to formalise these trends and analyse them in respect of different categories of the population and modes used?

Any assumption that car ownership and individual car use could grow indefinitely over time would seem far removed from practical reality. Consequently, if there is an upswing in the years to come, the saturation point will be ultimately be reached thereafter, to be followed by a possible decline. Assuming that the recently observed slowdowns are in fact a harbinger of peak car use, we propose to determine the levels involved on the basis of the French case. We therefore excluded the first hypothesis, but we shall make no judgement as to whether peak car use is permanent or not. In other words, we shall not discriminate between scenarios two and three, depending on whether the peak corresponds to a long-term saturation or a maximum preceding a downturn.

Despite one of Europe's highest fertility rates, the demographic profile in France is one of low population growth and a certain degree of ageing. In the European territory of France, the growth forecast is for $0.38 \%$ per year between 2010 and 2030 . In addition, the proportion of the population aged 65 or over rose from $11.4 \%$ in 1952 to $13.9 \%$ in 2000 and $16.7 \%$ in 2010 and is expected to reach $23.2 \%$ in 2030 and $26.2 \%$ in 2050 (INSEE projections). 
Against this background, how does the levelling-off of car traffic since the 2000s, especially in the most heavily urbanised areas, tie in with the long-term trend towards the spread of automobiles from the well-to-do to modest segments of the population? We shall describe this process from 1974 until 2010, in France as a whole and in Île-deFrance, making a distinction between four quartiles of household living standards. At each date, average households of the income distribution quartiles by unit of consumption are called Q1 to Q4, from the most modest to the most well-to-do. Going back to around the first oil shock, we have access to comparable annual surveys: INSEE monthly consumer confidence surveys (ECAMs) until 1994 and the car fleet (Parc-Auto) panel thereafter. Because these panels re-question the same households at least two years running, it is possible to detect changes in behaviour and to improve accuracy significantly when estimating time series.

In order to situate car peak levels, our approach is one of aggregated time series, focusing attention on segments of the population likely to exhibit pioneering behaviour: the most well-to-do households (less held back by financial constraints) and residents of Île-de-France (who had cars before provincials but are constrained by density and served by a good public transport network). Saturation, represented graphically by a sigmoid curve, appears as an intermediate hypothesis between a resumption of growth and decline; moreover, linking the level of the distance-travelled asymptote to fuel prices could explain the observed reversal of the trend.

\section{Second cars have succeeded first ones as the vector of increased car ownership}

In France as a whole, the rate of car ownership amongst modest households has practically caught up with that of the most well-to-do: the proportion of carless firstquartile households dropped from $55 \%$ in the mid-1970s to $35 \%$ in the mid-90s.

It is second cars that have constituted the primary vector in reducing car ownership inequalities. Multiple ownership in fact tended to rise with living standards until 1990. Subsequently, Q2 and Q3 grew close together and exceeded Q4, since the most affluent households tend to live in densely populated areas, and particularly in Île-de-France (Figure 4).

Insofar as multiple car ownership no longer shows significant differentials, depending on living standards, the social distribution of cars has reached its limits. In Île-de-France, inequalities stopped declining in the early 1980s, and then the trend reversed in the latter half of the $90 \mathrm{~s}$, with inequalities of car ownership now slightly more pronounced than in France as a whole.

Nationally, curves tracing the average number of cars per adult slope upward and are concave, whatever the standard of living (Figure 5); the hierarchy of car ownership levels is consistent with living standards throughout the period under study. The same holds true in Île-de-France (Figure 6), with the Q1 curve levelling off after having practically caught up with Q2 around the early 80s and car ownership among the most affluent households remaining flat since the mid-90s. 
Figure 4. Trend in household multiple car ownership in each income quartile, by consumption unit, France as a whole

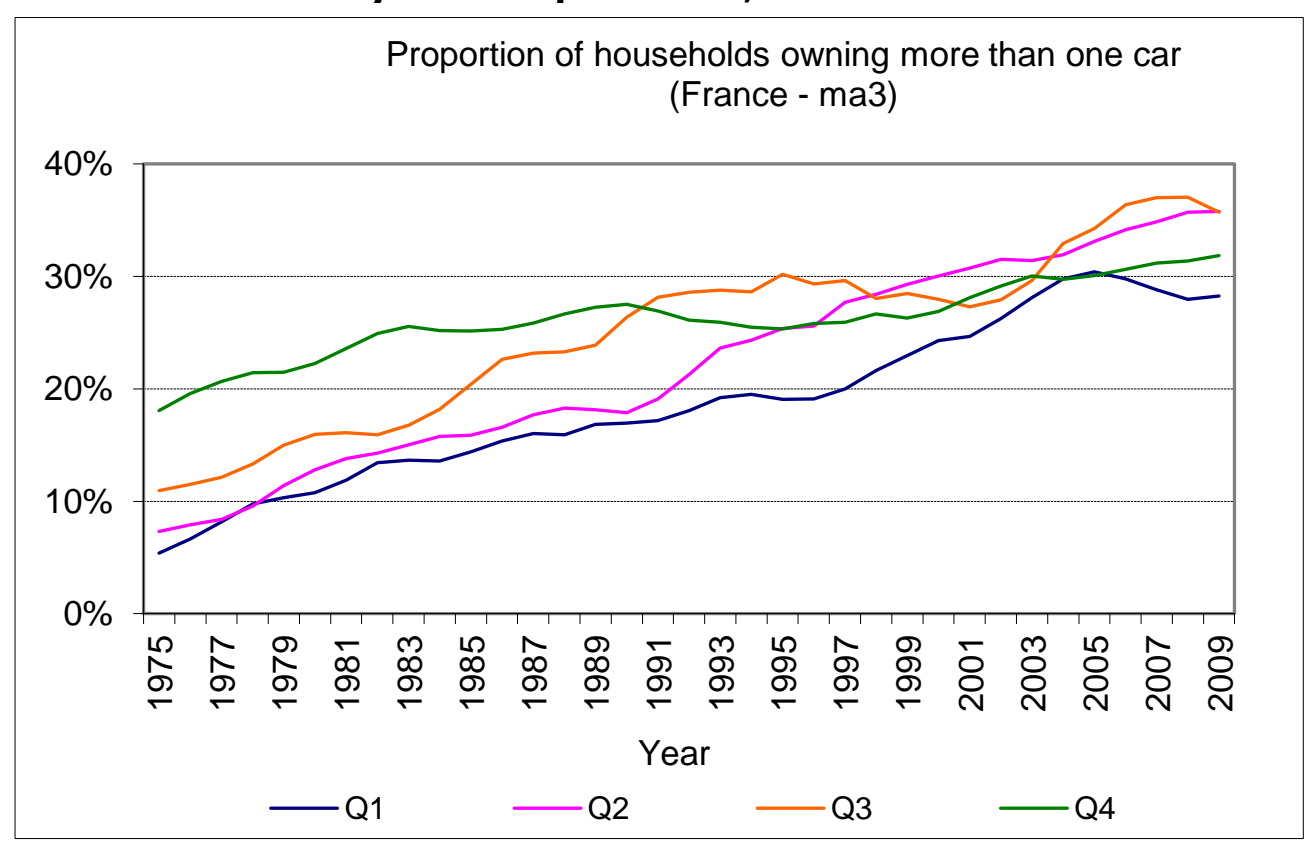

Source: DEST-IFSTTAR - ma3 = moving average over three years

Figure 5. Trend in the average number of cars per adult in each income quartile, by consumption unit, France as a whole

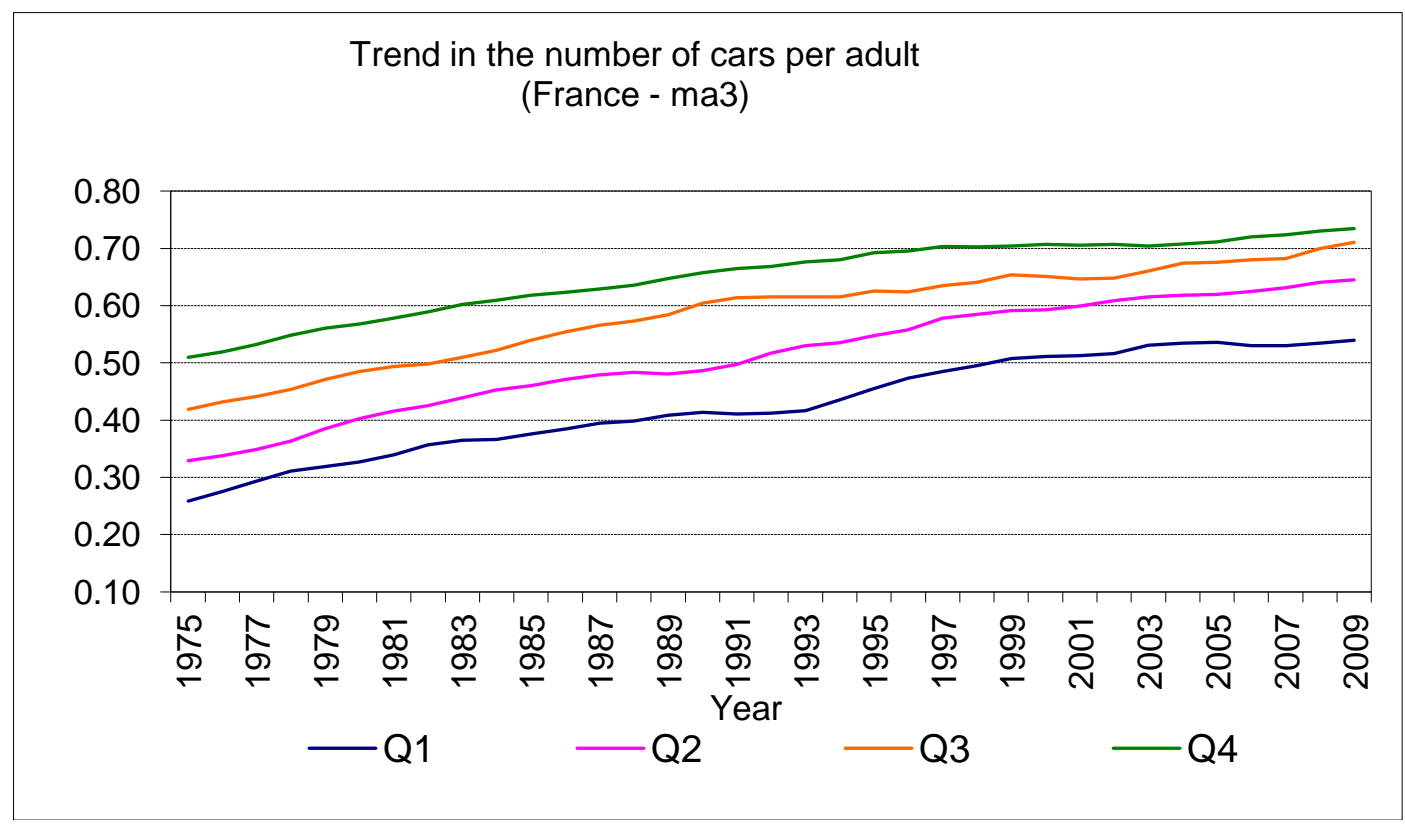

Source: DEST-IFSTTAR - ma3 = moving average over three years 
Figure 6. Trend in the average number of cars per adult in each income quartile, by consumption unit, île-de-France

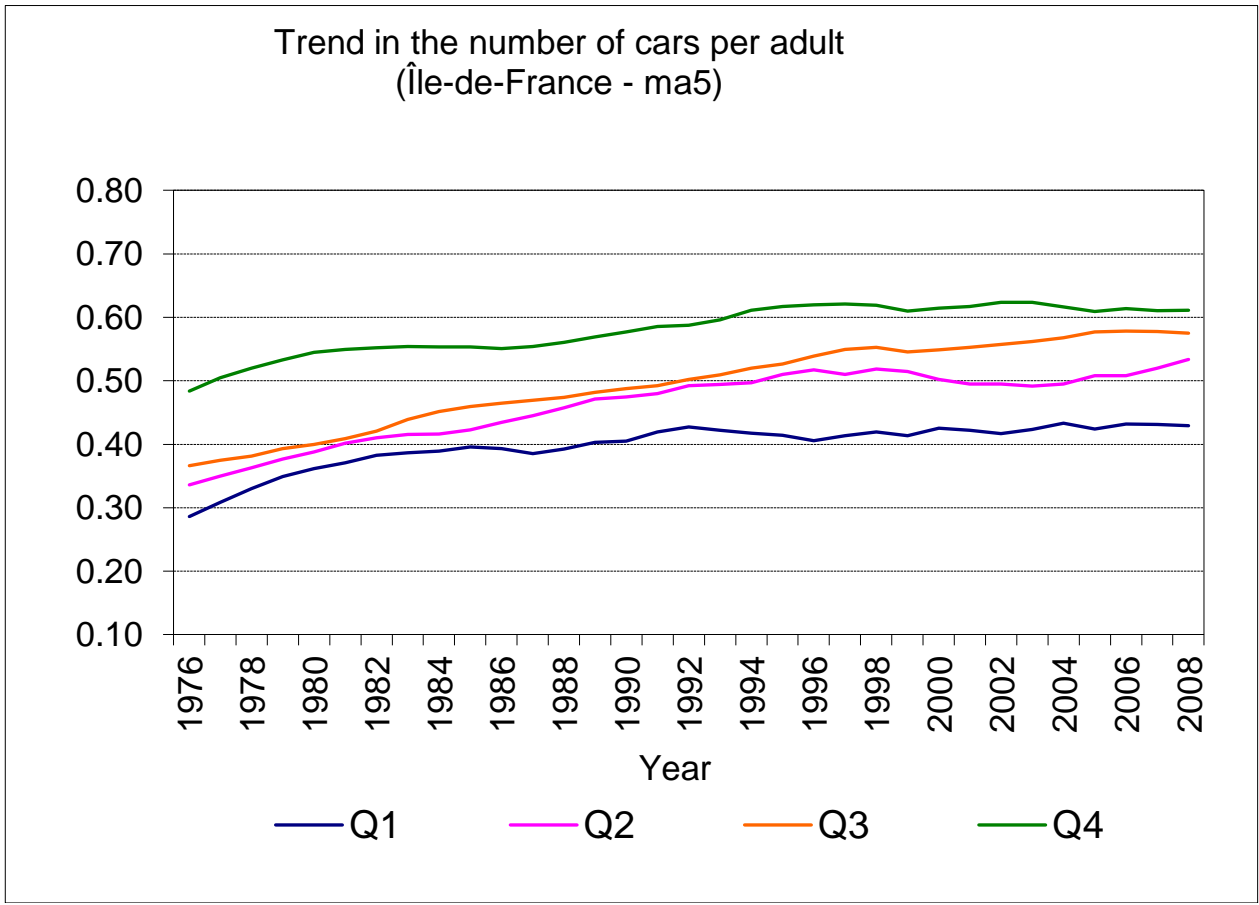

Source : DEST-IFSTTAR - ma5 = moving average over five years.

\section{The spread of car use modulated by fuel price fluctuations}

After the two oil shocks of the 1970s and a levelling-off in the first half of the 80 s, the cost of car use declined - first because of the 1985-86 counter-shock, and then because of the rising proportion of diesel-powered cars due to lower taxes on diesel fuel. On the whole, the average distance driven by households increased until 2000 (Figure 7), and then, since car ownership did not decline, decreased because of the average distance driven per car, which stemmed from rising fuel prices. After peaking in 2000 , fuel prices rose continuously from 2004 until mid-2008 and then fluctuated widely, setting a new record in the spring of 2012. The curves corresponding to Q1, Q2 and Q4 followed the same general pattern; that of Q3 peaked in the 1990s.

The decrease in distance travelled is more distinct for inhabitants of large cities than for people living in less densely populated areas. For people living in Île-de-France, for example, the levelling-off began in the early 1980s for Q4, and in the first half of the 90s for Q3, and in the latter half of the 90s, and thus before the 1999-2000 peak, for Q2 (Figure 8). Q2, Q3 and Q4 seem to converge at the end of the period, whereas Q1 stands apart. When fuel prices rise, it is harder for the poorest households than it is for others to reduce their already-low car use if they do not have public-transport alternatives. 
Figure 7. Trend in average annual distance travelled per household in each income quartile by consumption unit, France as a whole

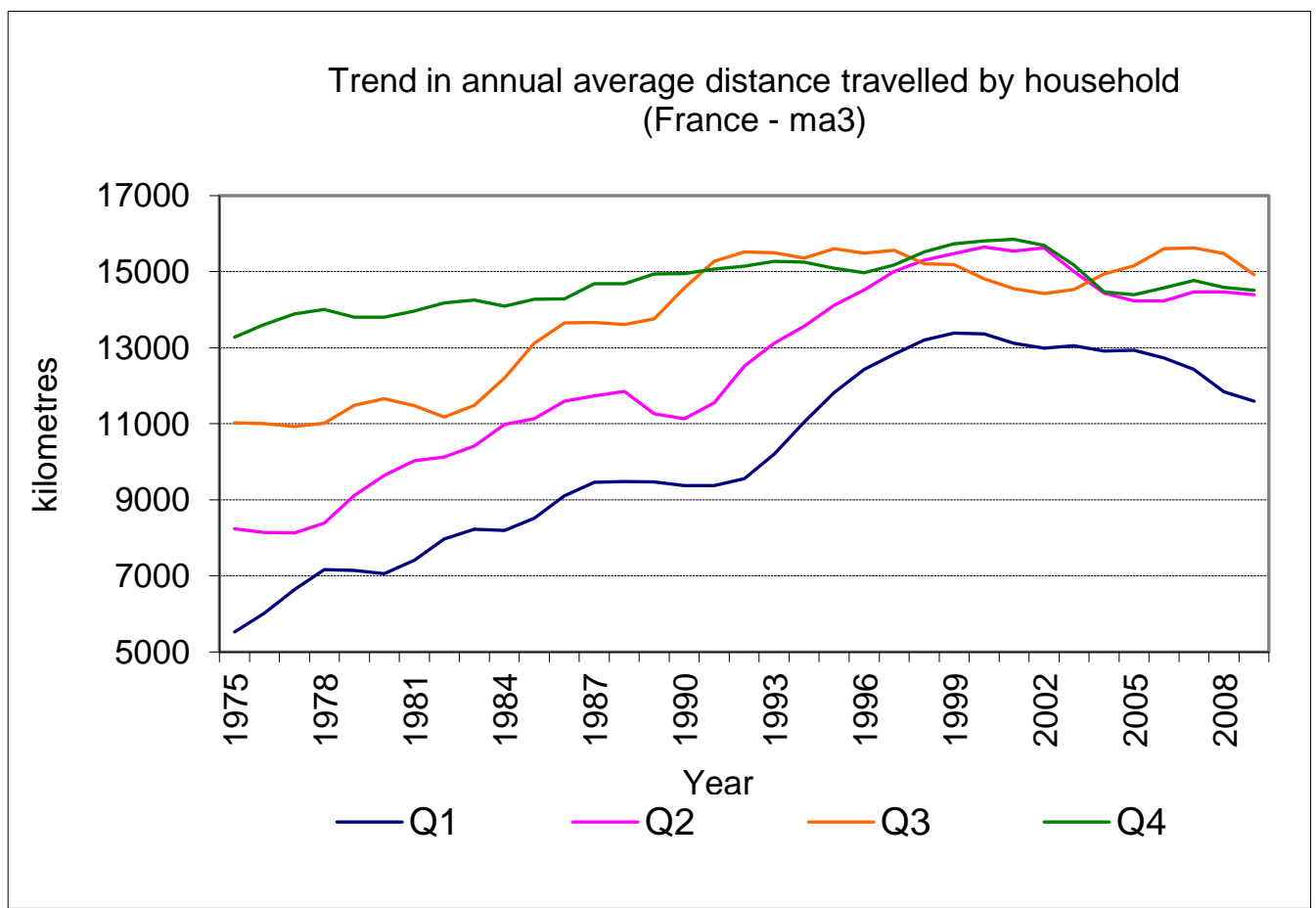

Source: DEST-IFSTTAR - ma3 = moving average over three years.

Figure 8. Trend in average annual distance travelled per household in each income quartile by consumption unit, île-de-France

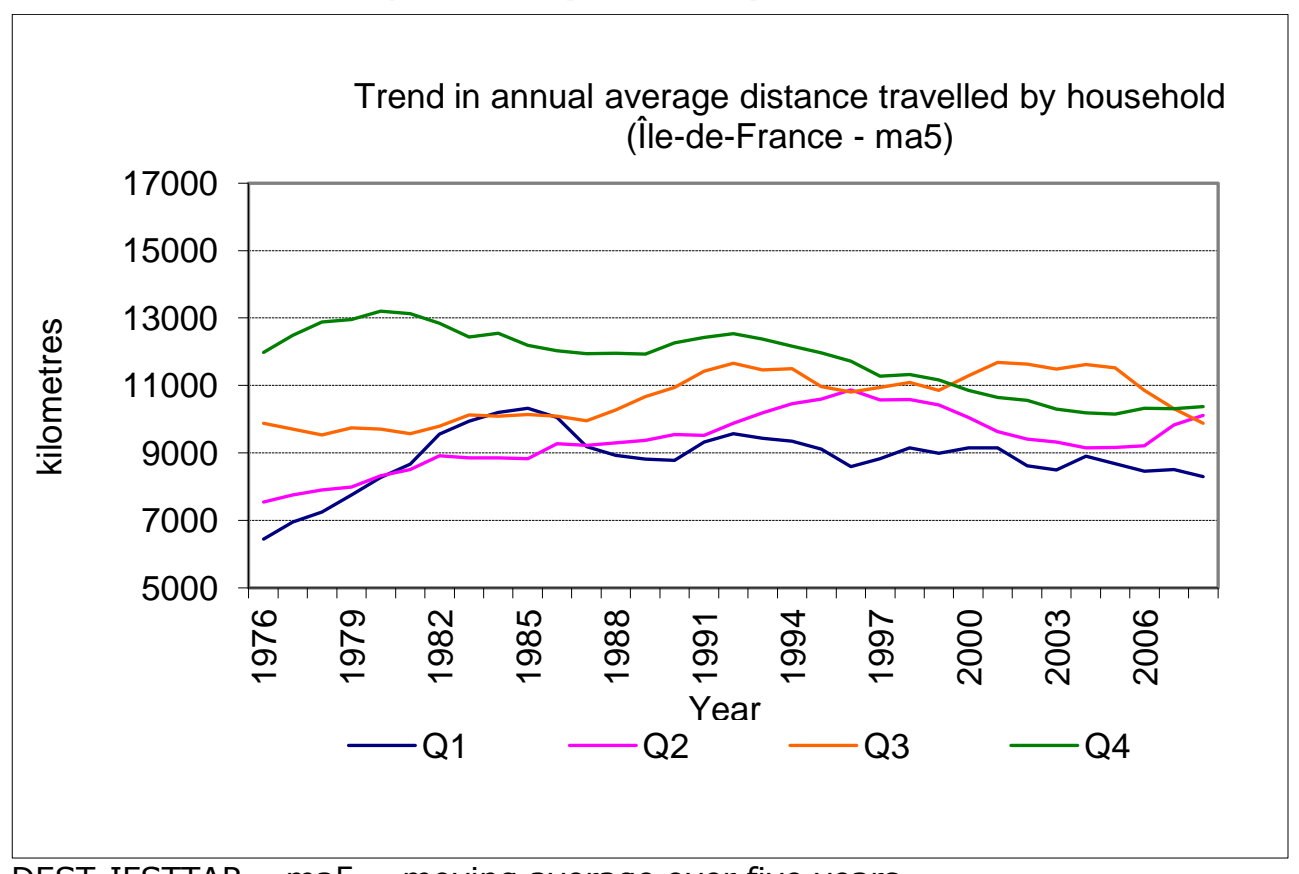

Source: DEST-IFSTTAR - ma5 = moving average over five years. 
Finally, after a period of status quo between the mid-1980s and the mid-90s, the social distribution of car ownership picked up again as it had in the 1970s, especially in the least densely populated areas, where dependency on automobiles is greater, for lower income households in particular [Dupuy, 1999].

\section{What are the limits on the growth of car ownership and car use?}

Theoretically, the social distribution of an asset over time can be represented by a sigmoidal curve tending towards an asymptote - the level of saturation. If it is assumed that the car-related behaviours dealt with here follow this pattern, which is consistent with the levelling-off of traffic observed in the 2000s, our data collected since the mid1970 s essentially cover the upper portion of the sigmoid. We adjusted the ChapmanRichards model [Richards, 1979] separately for each quartile, and then for all households.

With respect to car ownership in France as a whole (Table 2), the inflection dates are staggered from 1961 for Q4 to 1972 for Q1: they are therefore well prior to the beginning of our observations and suggest that car ownership trends are differentiated by quartile. In contrast, the saturation thresholds do not differ significantly: accordingly, in estimating the car ownership model we constrained it by a car ownership ceiling common to all quartiles. The estimate was fairly precise, its $95 \%$ confidence interval being $[0.74 ; 0.78]$ car per adult.

Table 2. Sigmoid curves adjusted to the average number of cars per adult France as a whole

\begin{tabular}{|c|c|c|c|c|c|c|c|}
\hline \multicolumn{8}{|c|}{$\begin{array}{l}\text { Model: Chapman-Richards (defined on 1920; }+ \text { inf) } \\
\text { Constraint ( } \mathrm{S} \text { and b4 common to all quartiles) } \\
\mathrm{R}^{2}=0.99959\end{array}$} \\
\hline $\mathbf{Y}$ & Coefficient & Std. dev & Student & $P>t$ & [95\% Conf. & Interval] & $\begin{array}{c}\text { Year of } \\
\text { Inflection }\end{array}$ \\
\hline$S$ & 0.7618565 & 0.009165 & 83.18 & 0 & 0.7437356 & 0.7799774 & \\
\hline $\begin{array}{l}\text { Quartile } 1 \\
\text { b1 } \\
\text { b3 }\end{array}$ & $\begin{array}{c}0.0328789 \\
0.825462\end{array}$ & $\begin{array}{l}0.0011699 \\
0.0128132\end{array}$ & $\begin{array}{l}28.11 \\
64.42\end{array}$ & $\begin{array}{l}0 \\
0\end{array}$ & $\begin{array}{c}0.0305659 \\
0.800128\end{array}$ & $\begin{array}{c}0.0351919 \\
0.850796\end{array}$ & 1973 \\
\hline $\begin{array}{l}\text { Quartile } 2 \\
\text { b1 } \\
\text { b3 }\end{array}$ & $\begin{array}{l}0.0461801 \\
0.9015596\end{array}$ & $\begin{array}{l}0.0018558 \\
0.0103673\end{array}$ & $\begin{array}{l}24.88 \\
86.96\end{array}$ & $\begin{array}{l}0 \\
0\end{array}$ & $\begin{array}{l}0.0425109 \\
0.8810616\end{array}$ & $\begin{array}{l}0.0498494 \\
0.9220575\end{array}$ & 1970 \\
\hline $\begin{array}{l}\text { Quartile } 3 \\
\text { b1 } \\
\text { b3 }\end{array}$ & $\begin{array}{l}0.0552784 \\
0.9188615 \\
\end{array}$ & $\begin{array}{l}0.0030402 \\
0.0134812\end{array}$ & $\begin{array}{l}18.18 \\
68.16 \\
\end{array}$ & $\begin{array}{l}0 \\
0\end{array}$ & $\begin{array}{l}0.0492673 \\
0.8922069\end{array}$ & $\begin{array}{l}0.0612895 \\
0.9455161\end{array}$ & 1965 \\
\hline $\begin{array}{l}\text { Quartile } 4 \\
\text { b1 } \\
\text { b3 }\end{array}$ & $\begin{array}{l}0.0654347 \\
0.9312386 \\
\end{array}$ & $\begin{array}{c}0.0055028 \\
0.020351\end{array}$ & $\begin{array}{l}11.89 \\
45.76 \\
\end{array}$ & $\begin{array}{l}0 \\
0\end{array}$ & $\begin{array}{c}0.0545548 \\
0.891001\end{array}$ & $\begin{array}{l}0.0763147 \\
0.9714762\end{array}$ & 1961 \\
\hline
\end{tabular}

Sources: ECAMs 1974-94, Parc-Auto 1994-2010

In Île-de-France, the ceilings on ownership rates depend to a significant extent on household living standards: the $95 \%$ confidence interval for the most modest quartile is $[0.41 ; 0.43]$ car per adult, $[0.52 ; 0.57]$ for the second quartile, and $[0.59 ; 0.69]$ for the third. However, no significant difference is observed between the third quartile and the fourth, most well-to-do, quartile, for which the ownership rate ceiling is estimated at between 0.61 and 0.65 car per adult. Because of the high population density in greater 
Paris, estimated car ownership rates in Île-de-France are all significantly lower than those previously calculated for France as a whole ( 0.76 car per adult).

For annual distances travelled per household, the lower the household standard of living, the more recent the inflection dates, which are staggered between 1952 and 1974 (Table 3).

This assumption being acceptable on the face of the data, we estimate a model constrained by a common ceiling $\boldsymbol{S}_{\mathbf{2}}$ and a common elasticity of fi. The usage ceiling at 2010 fuel prices was then estimated at $16200 \mathrm{~km} /$ year. It was thus calculated that the usage ceiling per household in France would drop by roughly $2400 \mathrm{~km}$ if fuel prices doubled relative to their 2010 level, falling to $13800 \mathrm{~km} /$ year.

\section{Table 3. Sigmoid curves adjusted to the average annual distance travelled by} household as a function of fuel prices, France as a whole

\begin{tabular}{|c|c|c|c|c|c|c|c|}
\hline \multicolumn{8}{|c|}{$\begin{array}{l}\text { Model: } \quad \begin{array}{l}\text { Chapman-Richards (defined on } 1920 ;+ \text { inf) } \\
\text { Constraint ( } \mathrm{S} \text { and } \mathrm{b} 4 \text { common to all quartiles) }\end{array} \\
\mathrm{R}^{2}=0.99704\end{array}$} \\
\hline $\mathbf{Y}$ & Coefficient & Std. dev & Student & $P>t$ & [95\% Conf. & Interval] & $\begin{array}{c}\text { Year of } \\
\text { Inflection }\end{array}$ \\
\hline $\begin{array}{c}\mathrm{S} \\
\mathrm{b} 4\end{array}$ & $\begin{array}{c}16305.55 \\
-0.2375254\end{array}$ & $\begin{array}{c}723.0406 \\
0.0515408\end{array}$ & $\begin{array}{c}22.5 \\
-4.61\end{array}$ & $\begin{array}{l}0 \\
0\end{array}$ & $\begin{array}{c}14875.88 \\
-0.3394373\end{array}$ & $\begin{array}{c}17735.22 \\
-0.1356135\end{array}$ & \\
\hline $\begin{array}{l}\text { Quartile } 1 \\
\text { b1 } \\
\text { b3 }\end{array}$ & $\begin{array}{l}0.046344 \\
0.926301\end{array}$ & $\begin{array}{c}0.0053069 \\
0.021461\end{array}$ & $\begin{array}{c}8.73 \\
43.16\end{array}$ & $\begin{array}{l}0 \\
0\end{array}$ & $\begin{array}{c}0.035851 \\
0.8838661\end{array}$ & $\begin{array}{c}0.0568379 \\
0.968736\end{array}$ & 1976 \\
\hline $\begin{array}{l}\text { Quartile } 2 \\
\text { b1 } \\
\text { b3 }\end{array}$ & $\begin{array}{l}0.0610387 \\
0.9560175\end{array}$ & $\begin{array}{c}0.0102628 \\
0.024079\end{array}$ & $\begin{array}{l}5.95 \\
39.7\end{array}$ & $\begin{array}{l}0 \\
0\end{array}$ & $\begin{array}{c}0.0407459 \\
0.308406\end{array}$ & $\begin{array}{c}0.0813314 \\
1.003629\end{array}$ & 1971 \\
\hline $\begin{array}{l}\text { Quartile } 3 \\
\text { b1 } \\
\text { b3 }\end{array}$ & $\begin{array}{l}0.0575344 \\
0.9138604\end{array}$ & $\begin{array}{l}0.0144213 \\
0.0647738\end{array}$ & $\begin{array}{c}3.99 \\
14.11\end{array}$ & $\begin{array}{l}0 \\
0\end{array}$ & $\begin{array}{c}0.0290192 \\
0.785783\end{array}$ & $\begin{array}{c}0.0860496 \\
1.041938\end{array}$ & 1963 \\
\hline $\begin{array}{l}\text { Quartile } 4 \\
\text { b1 } \\
\text { b3 }\end{array}$ & $\begin{array}{c}0.025962 \\
-0.115645\end{array}$ & $\begin{array}{l}0.0110172 \\
0.6507985\end{array}$ & $\begin{array}{c}2.36 \\
-0.18\end{array}$ & $\begin{array}{c}0.02 \\
0.859\end{array}$ & $\begin{array}{l}0.0041778 \\
-1.402471\end{array}$ & $\begin{array}{c}0.0477463 \\
1.171181\end{array}$ & $\begin{array}{c}\text { No } \\
\text { inflection }\end{array}$ \\
\hline
\end{tabular}

Sources: ECAMs 1974-94, Parc-Auto 1994-2010

In greater Paris, and in contrast to the results for France as a whole, the usage ceilings are estimated fairly precisely for each quartile of living standards. At a relative fuel price equivalent to that of 2010, the distance driven by the most modest quartile of Île-deFrance residents should peak to around $8600 \mathrm{~km} /$ year, 10000 for the second quartile and 10700 for highest two quartiles. The confidence intervals for these estimates are relatively narrow and would suggest significant differences amongst the first three quartiles. Elasticity to fuel prices does not differ significantly from one quartile to another; the constrained model estimates it at -0.31 .

By adjusting the sigmoid curves, the saturation points can be situated at approximately 0.76 car per adult and $16400 \mathrm{~km}$ per year and per household; this distance-driven ceiling is modulated by an elasticity of -0.24 , reflecting reactions to erratic fuel price movements. In Île-de-France, however, where traffic congestion is heavy and the network of public transit well-developed, the distances driven peaked earliest for the 
most well-to-do households, before the rising fuel prices of the 2000s, suggesting the onset of a major trend of which residents of Île-de-France were precursors.

\section{Behavioural changes or structural effect? A demographic approach}

Since the mid-20 $20^{\text {th }}$ century, car use in cities, as elsewhere, expanded continually at a sustained and regular pace, and no slowdown in the growth was perceptible. But starting in 2006, all of the household travel surveys started to show a levelling-off, and in many cases a decline, in car use, only a small portion of which can be explained by the shifting structure of the population (and ageing in particular) [Quételard, 2011]:

- In Lille, trends in the structure of the population should have brought about a slight growth in mobility (4.02 trips per person and per day in 2006, versus 4.00 in 1998), yet the observed average was 3.76.

- In Lyon, structural trends should indeed have brought about a drop in mobility, but the observed drop was much greater, from 3.63 in 1995 to 3.36 in 2006 (3.60 at constant structure).

- In Strasbourg, $10 \%$ of the drop in mobility of Urban Community residents was linked exclusively to population ageing, and the increase in the proportion of workers and students working or studying on an unbroken-day basis mechanically explains $20 \%$ of the drop in mobility [ADEUS, 2010].

Are these behavioural changes linked to the economic situation or to structural effects? To try to answer this question, we analysed the case of the Urban Community of Lille, where household travel surveys were carried out in 1987, 1998 and 2006, adjusting a demographic Age-Cohort projection model so as to isolate structural age and generational effects arising from the life cycle.

For Lille, we applied the Age-Cohort model [described in Bussière, Madre, Armoogum, 1996 ] to a variety of mobility variables for the period 2000-2030. One initial conclusion is that because people travel less above a certain age, population ageing has a definite impact, but this is only a partial explanation for the levelling-off of mobility observed in the 2000s. Population ageing, which reduces the weighting of young people, amplifies the levelling-off phenomenon.

Calibrating the model requires at least two years of observations with a fairly distant interval between them. From the three survey years available (1987, 1998 and 2006) we successively calibrated the model with all three years, with 1987 to 1998 , and with 1998 to 2006. Each of the three estimations yield very different results, since the levelling-off of mobility was noted only at the time of the last survey. The more recent the calibration data, the higher the levelling-off point. Based on the two last calibrations, we obtained the following results. Projecting forward to 2030, the proportion of adults holding driving licences should remain flat, as should the distance travelled per person in an individual car as either driver (Figure 9) or passenger, with a significant increase in the distance travelled per day per person in public transport (Figure 10). For example, beyond the renaissance of public transport observed in 2000, the model shows that its use could grow by more than $15 \%$ between 2000 and 2030, based on the 1987-1998 setting, and by $47 \%$ if the model is calibrated on the two most recent surveys. The significant differences observed between behaviours that prevailed until the 1990s and in the 2000s in fact explain the reversal of the tendency observed and lead to highly divergent projections, which for a long-term perspective once again raises the question of whether the recent trends are structural or cyclical. 
Figure 9. Age-Cohort model simulation, Lille 2000-2030.

Average distance travelled per day per person in kilometres, car drivers

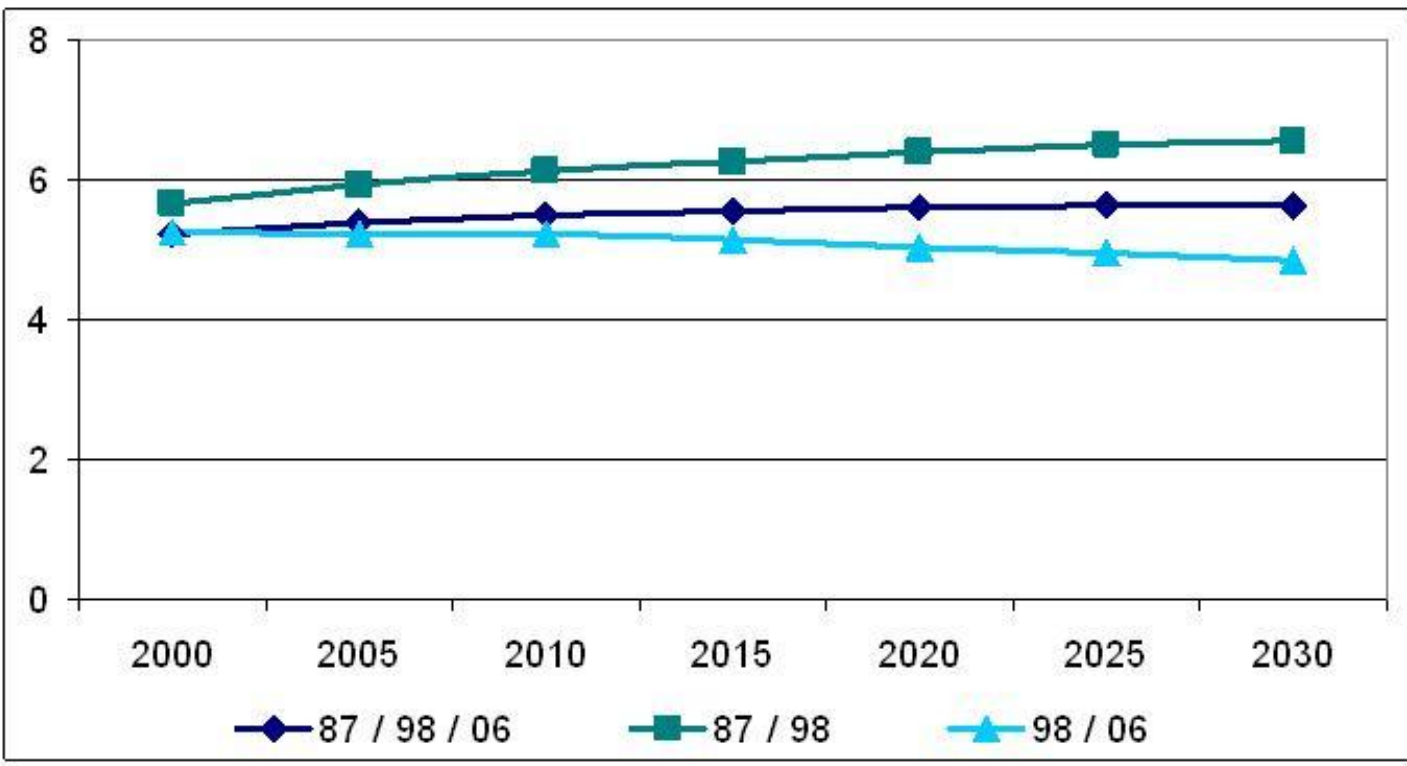

Figure 10. Age-Cohort model simulation, Lille 2000-2030, Average distance travelled per day in kilometres, public transport

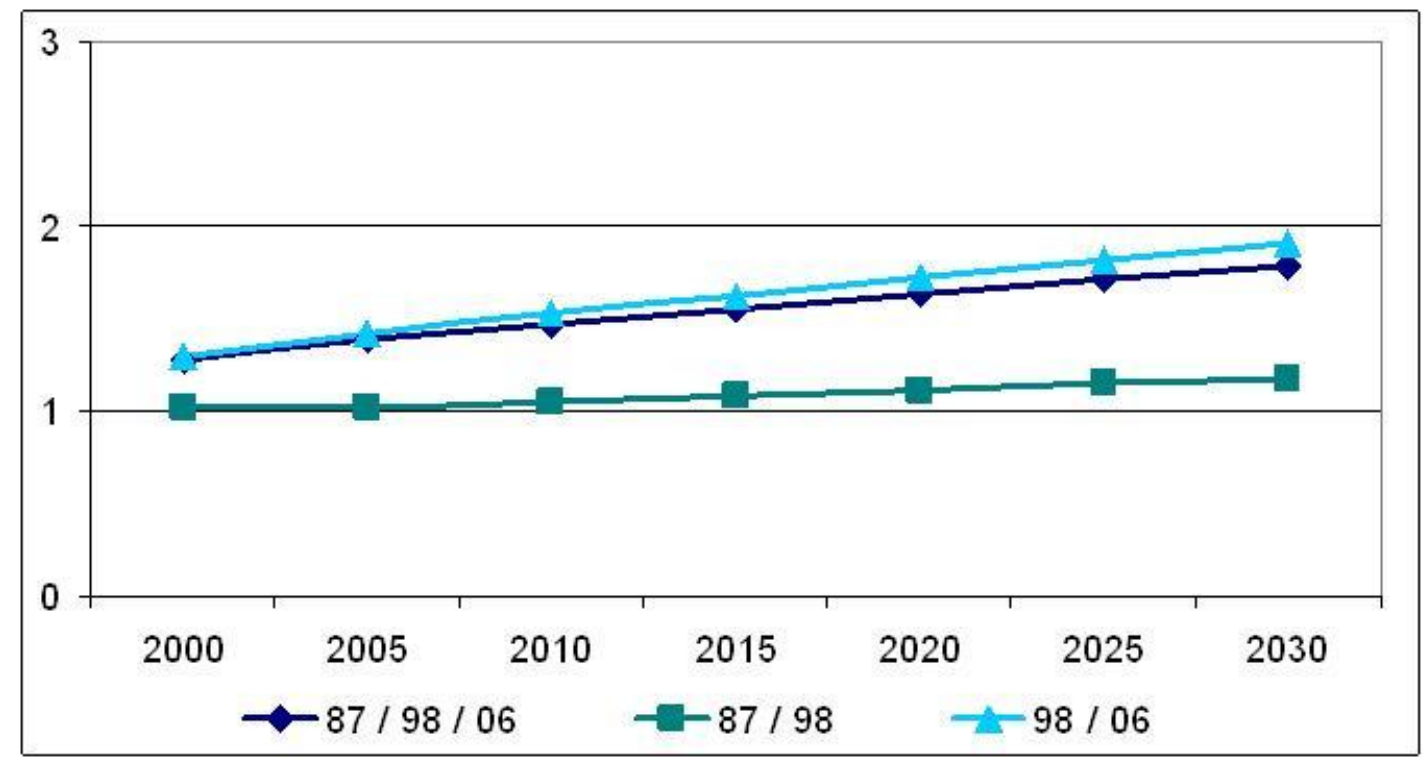




\section{The ageing factor in developed countries versus emerging economies - the example of Mexico}

An initial simple approach for measuring the impact on mobility of the shifting age pyramid is to apply sustainable transport behaviours to an age pyramid that is shifting over the long term. Here we shall show such a shift, using a comparison between Montreal and Puebla. The linkages between age or life cycle, mobility and modal choice are well established and relatively stable over time. As can be observed in the figures below, general mobility is bell-shaped. In Montreal, in 1993, it peaked at around age 35, and declines regularly thereafter until advanced ages. In Puebla, for the same year (1993-94), a virtually identical curve can be observed, but with a lower overall level of mobility. With regard to modal choice, car driver mobility is bell-shaped, peaking in Montreal at about age 40. The form of the curve in Puebla is similar, peaking somewhat later, at about age 45 albeit at a lower level. Public transport being in direct competition with cars, the observed curve is U-shaped in the case of Montreal and adopts a similar form in the case of Puebla (see Figures 11 to 13). The combined result of these trends will inevitably yield high individual car use in active age groups, translating into car $/ \mathrm{km}$ such as can be noted in the United States for the period 1995-2001-2009, where a decrease in car $/ \mathrm{km}$ can be seen in respect of the youngest drivers, but an increase for the over-65 age groups (Figure 14).

In the absence of survey data spanning a long period, we have assumed stable mobility behaviours and applied those behaviours by five-year age brackets over a long period using the cases of Montreal and Puebla. In Montreal's case, we rediscovered an exercise that we had done 22 years ago, but which at the time had left transport engineers sceptical. We projected 1982 behaviours over a 40-year time span (1971-2011) (Figure 15) [Bussière, 1993]. For lack of detailed demographic data over a long series for the city of Puebla, we redid the same exercise using population data from Mexico, projecting Puebla's 1993-94 behaviour over a 100-year period (1950-2050) (Figure 16). To validate the methodology we did another simulation on 2000-2050 demographic data, which yielded similar results.

What conclusions can be drawn? These simulations are obviously not projections of past and future demand because they do not factor in behavioural changes related to lifestyles and urban contours. They do, however, make it possible to isolate the demographic factor. In the case of Montreal, where the baby boom had been very substantial and followed by a sharp drop in birth rates, from the 1970 s until the late 90 s there was an exponential increase in pressures towards individual car ownership and a decline in public transport, with individual car ownership reaching an inflection point in 2001, followed by a decline. This was exactly the same trend as was observed in the great majority of developed cities (Figure 1). Without prejudice to other factors (urban contours, access to cars, lifestyle), it can therefore be concluded that the demographic impact on trends in individual car ownership is substantial, and that we are currently witnessing a saturation effect in respect of that impact. 
Figure 11 . Overall mobility by age, Montreal and Puebla (1993) (Trips per day by age) Trips/Pop.

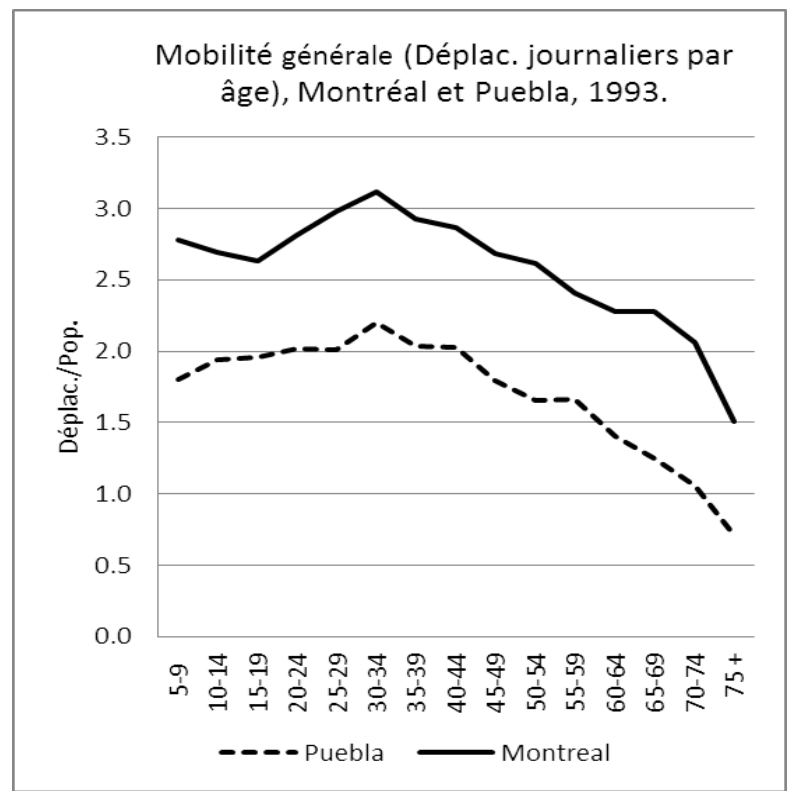

Source: Household Origin-Destination Surveys.

Figure 12. Modal choice by age Car driver and Public transport (PT), Montreal (1982-1987)

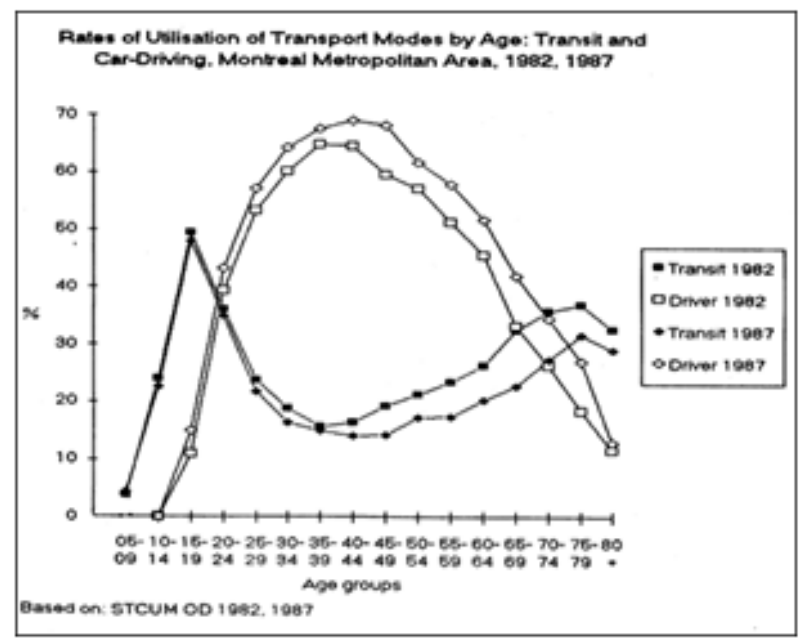

Source: Household Origin-Destination Surveys.
Figure 13. Modal choice by age Car driver and Public transport (PT) Puebla (1993)

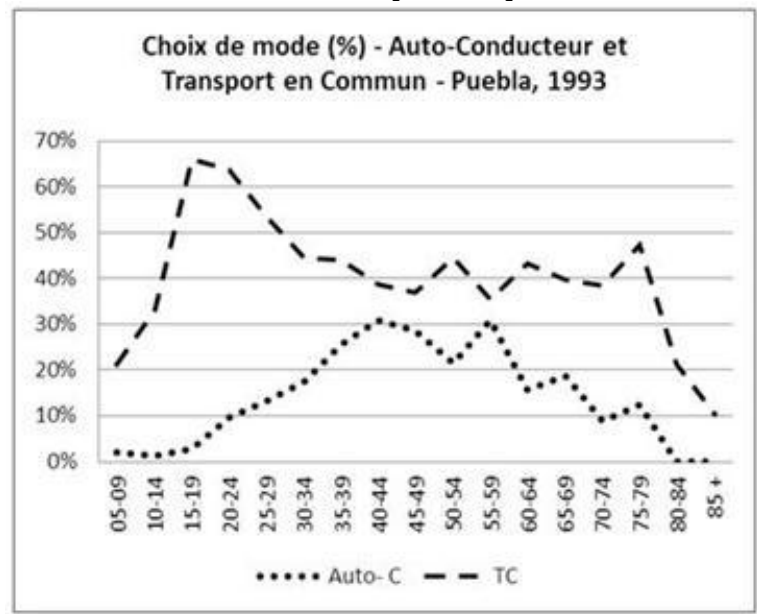

Source: Household Origin-Destination Surveys

Figure 14. Annual vehicle-miles per driver by age USA, 1995, 2001, 2009

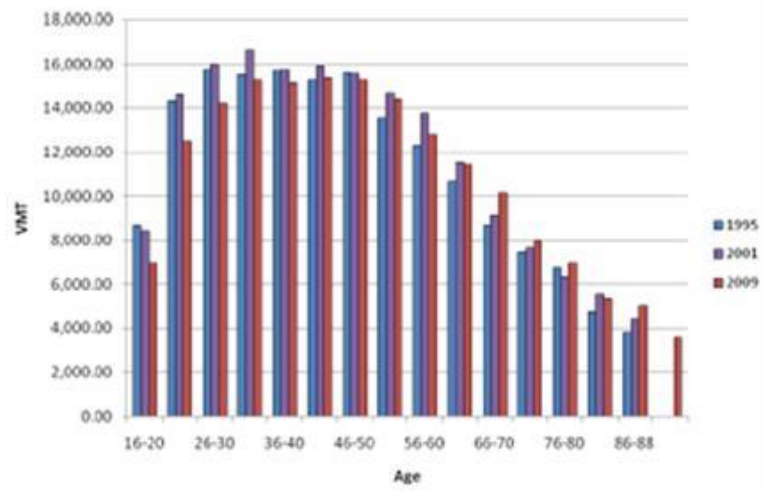

Source: OECD/ITF (2011), p. 29, pdf, www. 
In emerging economies, populations are still young, but the ageing phenomenon will arrive there as well. In Mexico, population growth, which had been very rapid until recently (averaging $1.58 \%$ per year between 1990 and 2010) can be expected to slow. The annual growth rate should average roughly $0.67 \%$ between 2010 and 2030, with rapid and substantial ageing (the proportion of people aged 65 or over was $3.4 \%$ in $1950,4.2 \%$ in $1990,6.4 \%$ in 2010 and is forecast to be $12.5 \%$ in 2030 and $22.0 \%$ in 2050), according to CONAPO projections. In the cities, growth should be slightly more rapid because of a continuing rural exodus. A simulation on greater Puebla shows the beginnings of demographic pressures conducive to individual car ownership around the year 2000, at the same time that a slowdown was being observed in developed cities. There ensued some three decades of heavy demographic pressure conducive to individual car ownership and a slowdown in public transit. The inflection point is to come at around 2035, after which there will be a slowdown in individual driving and a virtual levelling-off for public transport. What conclusions can be drawn from this? This simulation represents a minimalist scenario because it assumes a continued low level of car ownership. If the growth in living standards and household car ownership factor is added in, the result would be explosive for at least another 20 years. A recent household origin destination transport survey in Puebla (2011) gives us interesting input with which to complete the picture. Between 1994 and 2011, per capita mobility remained stable (at 1.75 trip per day per person), as did individual car ownership, which followed population growth (up 50\%), but persistent poverty did not allow household car ownership to increase. On the contrary, the proportion of households with cars fell to $33 \%$ in 2011 , as compared to $39 \%$ in 1994, and the proportion of households with more than one car was only $3.8 \%$ in 2011 versus $10.3 \%$ in 1994 . To a large extent, this trend reflects the persistence of poverty. While in $199419.0 \%$ of households suffered from food poverty, the rate did not change in 2008, with 19.5\% (Figure 17) [Coneval, 2009]. In addition, over the same period, the average age of cars on the road increased from 9.4 to 13.0 years. A 2012 survey in the city of Colima on the west coast of Mexico indicated an average age of household cars of 13 years. In France, there has been an ageing of the cars on the road, the average age of which increased from 6.2 years in 1993 to 8.2 years in 2007 [Kolli, 2012], but for quite different reasons: the greater number of second cars, which are driven less and last for longer.

To round out this initial analysis with a more complex methodology that incorporates a greater number of factors, we applied the Age-Cohort model to two Mexican cities for all travel. For Puebla over the period 1996 to 2030, based on 1994 and 2011 surveys (Figure 18); and for Ciudad Juárez over the period 1996 to 2030, using 1996 and 2006 surveys (Figure 19). In contrast to our initial purely demographic simulations, these simulations factor in behavioural changes by closely defined age groups, which indirectly incorporate a series of factors such as changing urban contours, income and lifestyle. In the case of Puebla, an inflection point is obtained in 2020, with subsequent decline. In the case of Ciudad Juárez, based on a slower demographic growth scenario given the current context of violence (projected average annual growth rates of $1.60 \%$ from 2006 to 2012 and $1.06 \%$ from 2015 to 2030), the inflection point appears earlier, in 2015, which could not be explained by population ageing, since only $5.4 \%$ will be aged 65 or over in 2015, but probably by a beginning of saturation of individual car ownership, with $72 \%$ of households having cars, as compared with $84 \%$ in France in $2007-08$, and $36.4 \%$ of households having more than one car, as compared to $38 \%$ in France in 2008 [Kolli, 2012]. Here, too, average vehicle age is increasing, rising from 11.7 years in 1996 to 13.8 in 2006, due possibly to multiple ownership, the persistence of relative poverty and the proximity of the US border, which facilitates lightly-taxed imports of vehicles aged ten years or more. 
Figure 15. Transport demand trends (All modes, public transport, Car-Driver) Montreal 1971-2011 $(1971=1)$

At constant 1982 behaviour

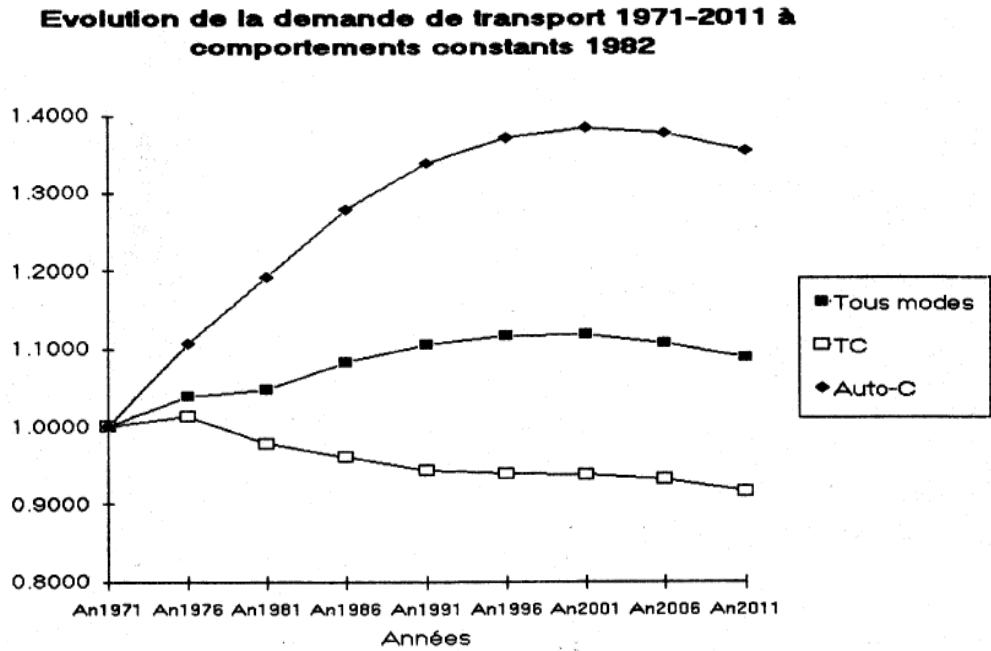

Source: Bussière \& Fortin, 1990, based on Traitements INRS 1971-2011.

Figure 16. Estimated mobility by mode, Puebla metropolitan area 1950-2050.

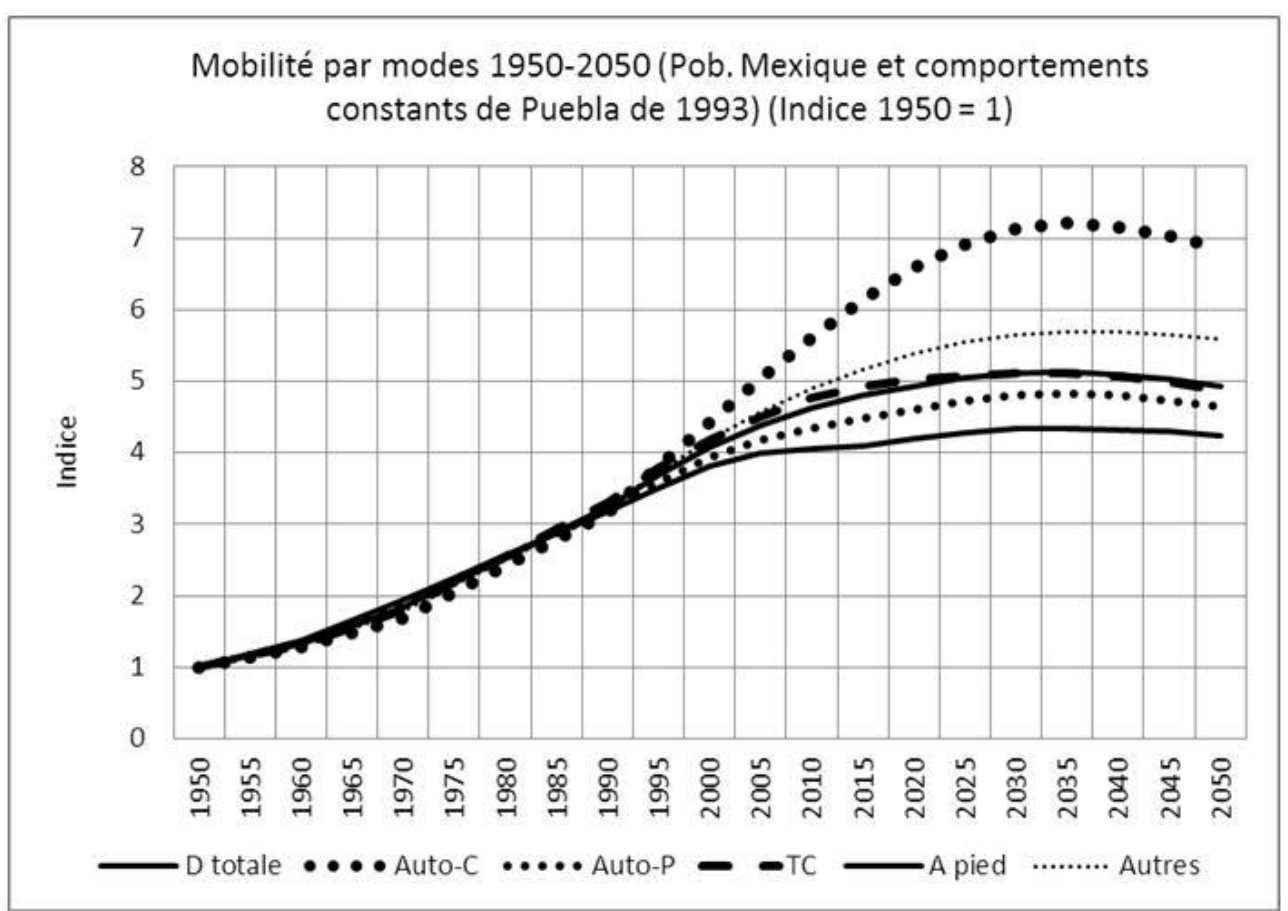

Source: Bussière, Oct. 1991. 
Figure 17. Poverty trends (food, capacities, wealth) Mexico, 1992-2008

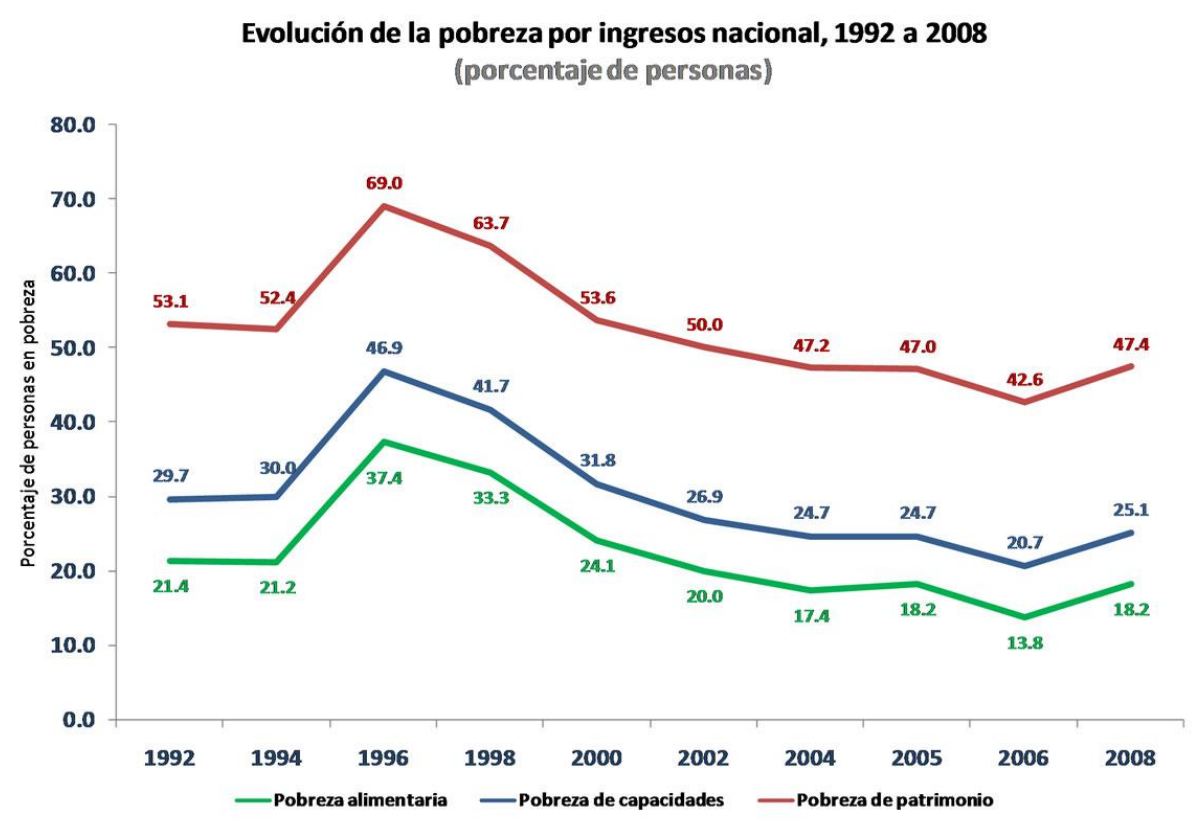

Source: Coneval (2009).

Figure 18. Simulation on Puebla - Distance in $\mathbf{~ k m ~ p e r ~ p e r s o n , ~}$ all modes combined - 19942030

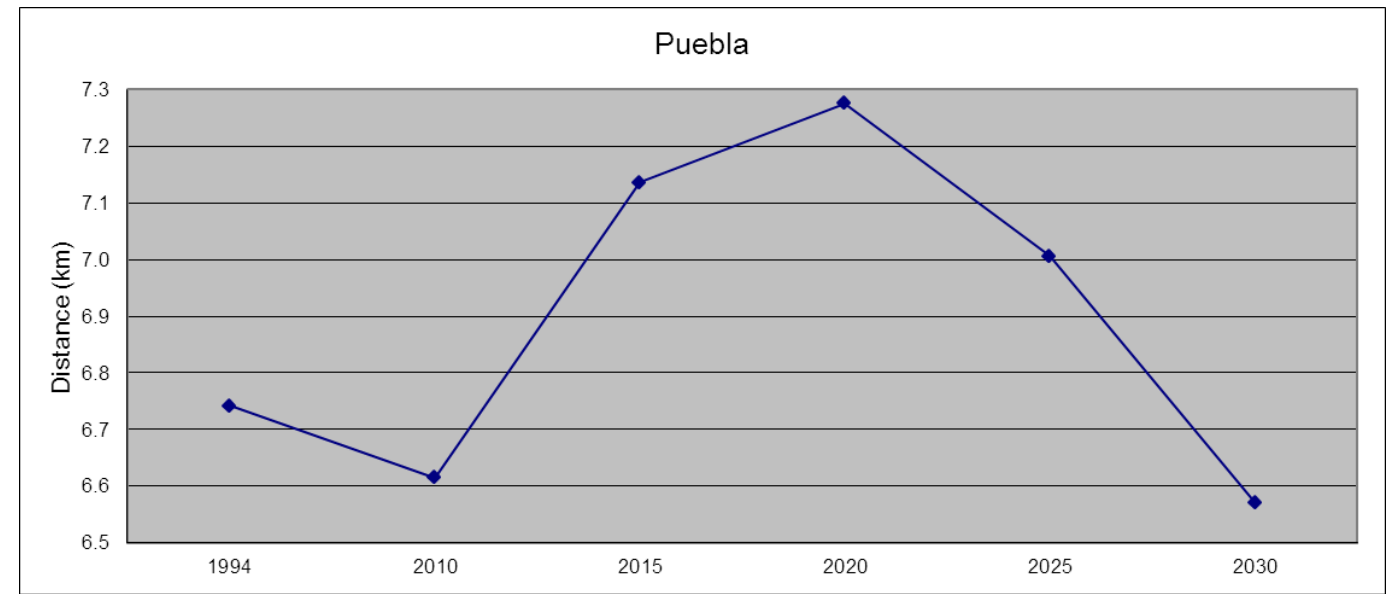


Figure 19. Simulation on Ciudad Juarez - Distance in $\mathbf{k m}$ per person, all modes combined - 1996-2030

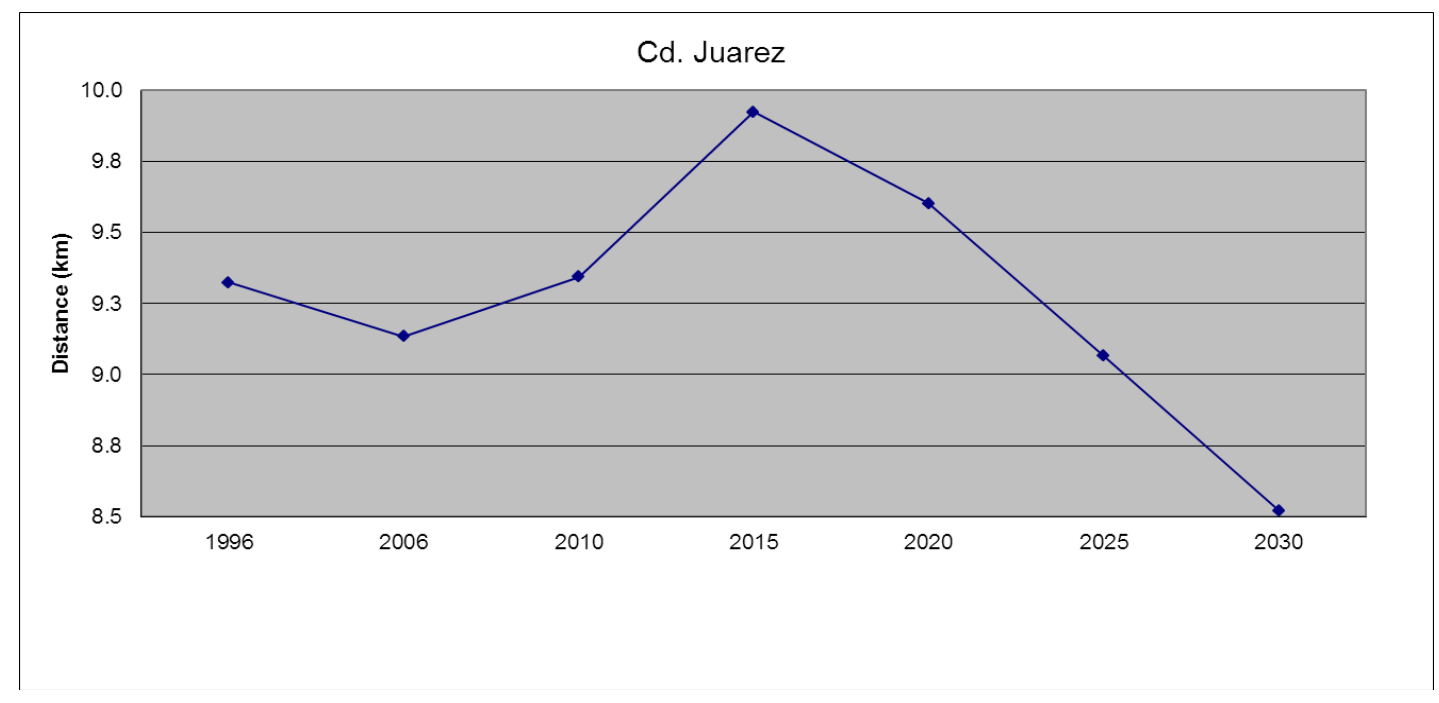

\section{CONCLUSION}

To summarise with respect to France, the main findings are as follows: the same trend towards a decline in mobility can be found here as in most other developed countries, starting in the early 2000s, whilst the average distance travelled by households was levelling off and dropped slightly thereafter, with cyclical variations probably linked to fuel price variations, a drop in the percentage of young people holding driving licences in the most densely populated urban areas (elsewhere, the opposite can be seen), the social distribution of car ownership, which is attaining its limits, with the decline in inequalities of automobile ownership and the widespread increase in second cars, an ageing of the cars on the road, a saturation of car ownership in Île-de-France and a slowdown outside the region. In addition, there can be seen significant growth in the use of public transport.

In our case studies in Mexico, we can also make out a saturation phenomenon that could take place in roughly 20 years in the most traditional cities and slightly earlier in more developed cities, provided there is a slowdown in population growth. The car population is old, however, and is not tending to get any younger, for lack of purchasing power, but also due to policies that encourage ownership of old vehicles, such as the annual vehicle tax from which cars aged 10 years or older are exempt - a tax that was recently abolished at the national level (federal tax) and in certain states (Puebla and Tlaxcala in 2011).

Given the finding that overall mobility as well as urban car mobility has reached a saturation point, or at the very least has been slowing in the developed countries, along with the probable appearance of a similar tendency in emerging economies, but only in about 20 years after intense pressure for individual car ownership, what can be concluded in policy terms? 
With respect to developed countries, in which the growth of cities is changing, there is an encouraging sign that it will be easier to shift the focus of urban transport planning: restrict car usage in the city, while promoting the use of public transport and soft modes; control urban extension by making suburbs denser and bolstering public transport systems; rethink the construction of toll roads at the periphery of metropolitan areas, which are perhaps no longer useful nor worthwhile economically; rethink our conception of quality-of-life in the city, with less emphasis on the fluidity of car travel; introduce various measures to manage demand in order to diminish the number of trips and car travel within cities. It would also be necessary to address the technology by imposing stricter standards on manufacturers; nevertheless, the impact on the production cycle and the renewal of cars on the road could take another two decades. The transition must therefore be accelerated [Schipper, 2011].

With respect to emerging economies, despite the great disparities from one country to another, and from one city to another, the example of Puebla and Ciudad Juárez can give us an idea of the magnitude of the challenge to be taken up in the years ahead: population growth will remain relatively strong for at least another one or two generations; it is likely that cities will expand in a way that is disordered and staggered; and socio-economic equality between households in terms of car ownership is only beginning, the great majority of transport policies favour the use of automobiles, along the lines of the US model from the 1970s, at least in Mexico and elsewhere in Latin America; most public transport is fairly rudimentary and not very competitive in relation to travel by car, and the absence of redistributive taxation makes it difficult, except in very large cities, to modernise it and introduce operating subsidies to make it more competitive; the public's lack of awareness of environmental issues; security problems are complicating the introduction of non-motorised modes, which cities in the north are adopting more and more. What, therefore, would be the most appropriate policies?

First, existing facilities must be strengthened. Many Mexican and Latin American cities built on the European model still have high population densities comparable to European cities. Policies should be crafted to maintain the density of city centres and avoid constructing ring roads without companion measures to avoid population flight from the centre to the periphery; modernising public transport to make it more competitive relative to cars and to change its image from a mode of transport for poor people to a mode of transport for everyone; to foster the introduction of pedestrian areas in city centres and in suburbs; foster continued use of bicycles in many cities where it has not yet disappeared; promote expansion of bicycle use for utilitarian and recreational purposes; regulate the fleet of cars to make it younger, with cleaner vehicles; disseminate information and facilitate procedures to have access to carbon vouchers that could finance these measures.

Yes, the trend towards ever-greater urban mobility, which seems to be reversing in the developing countries, can be expected to spread to a number of emerging economies, but only in a couple of decades. The challenges for sustainable transport are as great as ever. 


\section{ACKNOWLEDGEMENTS}

We should like to thank the Cuerpo Académico de Economía Urbana y Regional of the Economics Faculty of the Benemérita Universidad Autónoma de Puebla, as well as the Mexican National Council on Science and Technology (CONACYT) (subsidy CB-2011-01 No. 168388) for their support.

\section{REFERENCES}

ADEUS (Agence de développement et d'urbanisme de l'agglomération strasbourgeoise) (2010), "Baisse de la mobilité et modes de vie en evolution", Les notes de l'adeus, March.

Avrillier, P., Hivert, L., Kramarz, F. (2010), "Driven Out of Employment? The Impact of the Abolition of National Service on Driving Schools and Aspiring Drivers", 24 p., first published online: 17 Aug. 2010, Online ISSN: 1467-8543, published in the British Journal of Industrial Relations, Volume 48, Issue 4, December 2010, pp784-807, (c) Blackwell Publishing Ltd/London School of Economics.

BITRE (Bureau of Infrastructure, Transport and Regional Economics) (2012), "Traffic Growth: Modelling a Global Phenomenon", Report 128, Canberra ACT.

Bussière, Y. D. (October 2011), Paris (Marne-la-Vallée), Invited speaker, "Puebla: Évolution de la mobilité 1994-2011", IFSTARR, DEST. 27 Oct., Ppt, 54p.

Bussière, Y. and L. Fortin (1990), "Demande de transport et évolution démographique: rétroprojection et prospective", Communication, $14^{\text {th }}$ Annual Meeting of the Canadian Regional Science Association, University of Victoria, Victoria, Canada, 2-4 June, 26p.

Bussière, Y., Madre, J.-L., Armoogum, J., (1996), "Vers la saturation? une approche démographique de l'équipement des ménages en automobile dans trois régions urbaines", Population, No. 4/5, pp. 955-977.

CCTN (Commission des Comptes Transport de la Nation) (2012), Ministère de l'Écologie, du Développement durable, des Transports et du Logement. Les comptes des transports de la Nation en 2011. July.

Collet, Roger. (2012), "Household car use in France: a demographic and economic analysis", Economics Bulletin, 2012, Vol. 32, Issue 1, pp. 475-485.

Coneval - Consejo Nacional de Evaluación de la Política de Desarrollo Social (2009), Evolución de la pobreza en México. 24p. pdf. www.

Davis, B., Dutzik,T., Baxandall, Ph. (2012), "Transportation and the New Generation: Why Young People Are Driving Less and What It Means for Transportation Policy ?" Frontier Group U.S. PIRG Education Fund.

Dupuy G. (1999), "La dépendance automobile: symptômes, analyses, diagnostic, traitements", Paris, Anthropos.

Gardes F., Langlois S. and Richaudeau D. (1996), "Cross-section versus time-series income elasticities", Economics Letters, 51, p. 169-175.

Goodwin, Ph., (2010-2011), "Peak Car", series of five articles in Local Transport Today, June 2010-June2011" Local Transport Today, London, 14p.

Hivert, L., (Nov. 2011), "Short-term break in the French love for diesel?", accepted in Energy Policy, Corrected Proof in press, available on 25/11/2011, forthcoming in "Special Issue: Decades of Diesel" (2012?). 
Hubert, J.-P., (2009), "Dans les grandes agglomérations, la mobilité quotidienne des habitants diminue, et elle augmente ailleurs", INSEE Première No. 1252.

Hubert, J.-P., Madre J.-L., Roux S. (2010), "Changes in Fractioning Behaviour on Work Days", IATUR (International Association for Time Use Research), Paris.

Kolli, Zéhir, (2012), "Dynamique de renouvellement du parc automobile. Projection et impact environnemental", Doctoral thesis in economics, Université Paris 1. PanthéonSorbonne, 309p.

Kuhnimhohf, T., Armoogum, J., Buehler, R., Dargay, J., Denstadli, J.M., Yamamoto, T., (2012), "Trends in Young Adults' Behaviour: Evidence from Six Industrialized Countries", 90th TRB Annual Meeting, IFSTTAR, Working document.

Litman, T. (2011), "The Future Isn't What It Used To Be. Changing Trends and Their Implications For Transport Planning", Victoria Transport Policy Institute, 49p. www.vtpi.org/future.pdf .

Madre, J.-L., Armoogum, J. (1997), "Interview et présence au domicile" $14^{\text {th }}$ Annual International Symposium on Methodology Issues, Statistics Canada, Ottawa (publication of a condensed version in French and English).

Meissonnier J., (2011), "Le déménagement: un déclencheur des changements dans les choix modaux? Le cas de trois agglomérations du nord de la France", Dixièmes rencontres francophones Est-Ouest de socio-économie des transports, DRI - Ecole polytechnique de Montréal, 1-5 June 2011, Montreal, Canada.

Metz. D. (2010), "Saturation of Demand for Daily Travel", Transport Reviews, 30: 5, 659674.

Millard-Ball, A., Schipper, L. (2010), "Are We Reaching Peak Travel? Trends in Passenger Transport in Eight Industrialized Countries", Transport Reviews. http://www.tandfonline.com/doi/abs/10.1080/01441647.2010.518291.

Newman, P. and J. Kenworthy (2011), "'Peak Car Use': Understanding the Demise of Automobile Dependence", World Transport, Policy \& Practice, Vol. 17.2, June, Pdf 14p.

Noble, B. (2005), "Why are some young people choosing not to drive?" Proceedings of the European Transport Conference, Strasbourg.

OECD/ITF, International Transport Forum, (2011), "Peak car travel in advanced economies?", Chapter 3, Transport Outlook: Meeting the Needs of 9 Billion People, Paris.

Papon F. and Hivert L. (2008), "Adulterous behaviour within the car-owner couple: some analyses from French panel data on car rental and car sharing within households", IATSS Research, 32(2), pp. 6-15.

Quételard (2011), "Une rupture dans l'évolution de la mobilité urbaine: Les enseignements des dernières EMD", Atelier thématique RST Demande de Transport : méthodes de recueil, analyses et prospective, Certu, 6 December.

Richards F.J. (1979), "A flexible growth function for empirical use", Journal of Experimental Botany, 10, pp. 290-300.

Roux S. (2012), "Transition de la motorisation en France au XXème siècle", Doctoral thesis in demographics, Paris I - Panthéon - Sorbonne.

Schipper Lee (2011), "Automobile use, fuel economy and $\mathrm{CO}_{2}$ emissions in industrialized countries: Encouraging trends through 2008?", Transport Policy 18, pp. 358-372.

Sivak M, Schoettle B. (2012), "Recent changes in the age composition of drivers in 15 countries", Traffic Injury Preention, 13:126-132.

SOeS (2012), "La circulation routière augmente à un rythme ralenti depuis 2003", Le Point sur, No. 118, CGDD. www.statistiques.developpement-durable.gouv.fr TRANSPORT

STIF (2012), "Nouvelles mobilités des franciliens", http://www.stif.info/IMG/pdf/Enquête_globale_web.pdf http://www.stif.info/IMG/pdf/Nouvelles mobilites des franciliens 9 juillet2012.pdf. 
